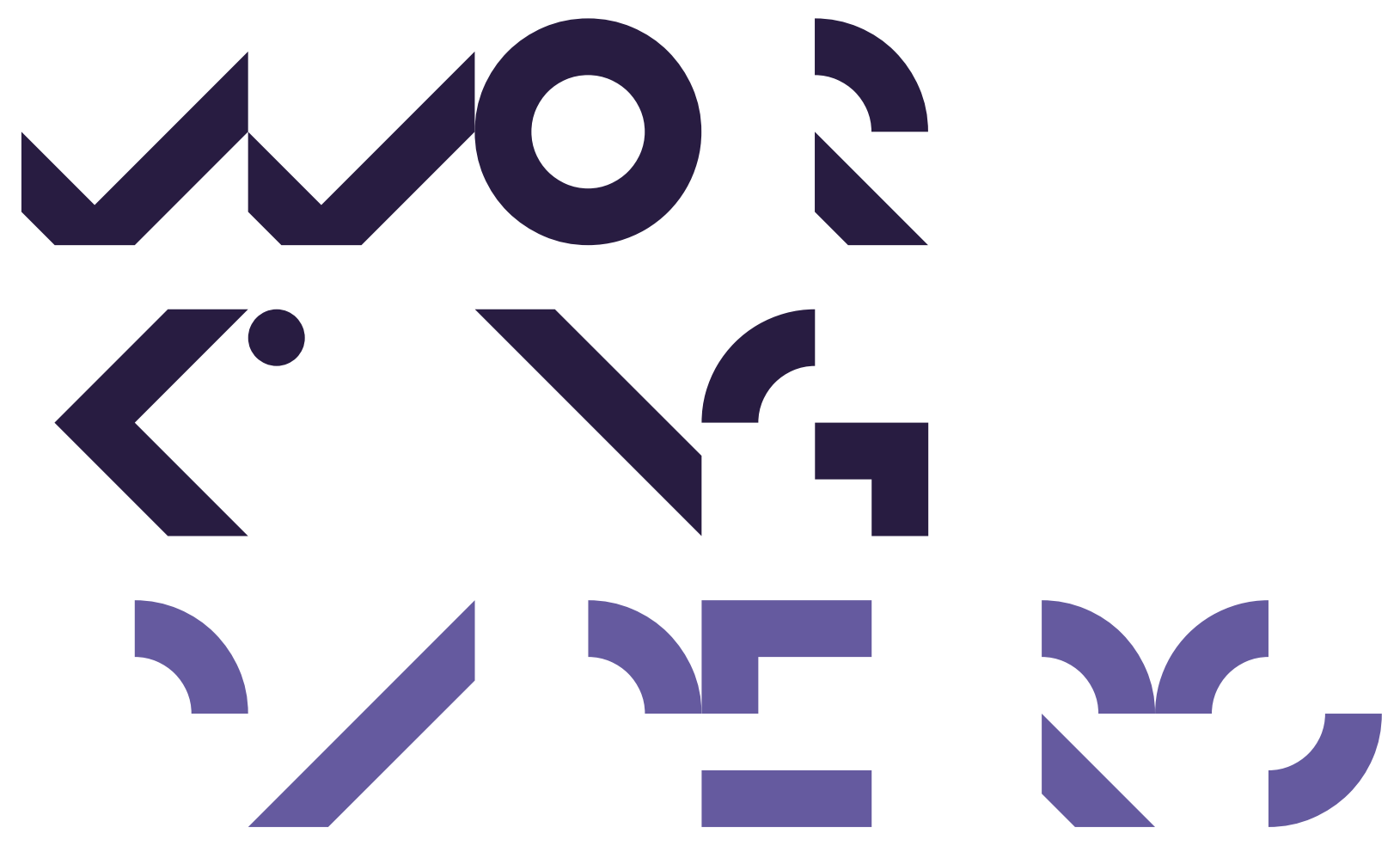

Economics Working Papers

2017-4

Foreign Ownership and Skill-biased Technological Change Michael Koch and Marcel Smolka

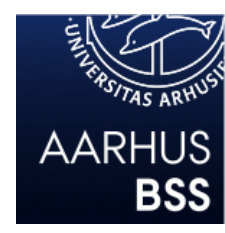




\title{
Foreign Ownership and Skill-biased Technological Change*
}

\author{
Michael Koch ${ }^{\S}$ \\ University of Bayreuth
}

\author{
Marcel Smolka \\ Aarhus University
}

May 22, 2017

\begin{abstract}
Understanding the effects of foreign direct investment and the behavior of multinational enterprises (MNEs) is a core issue in the study of international economics. We exploit within-firm variation in ownership structure induced by foreign acquisitions in Spain to provide a new angle on the relationship among foreign ownership, technology, and skills. We first develop a model in which heterogeneous firms decide endogenously about the level of technology, the share of highskilled workers, and the level of worker training. Foreign-owned firms implement better technology than domestically owned firms due to access to foreign markets through the foreign parent. This market size effect, coupled with a technology-skill complementarity, raises the demand for high-skilled workers as well as worker training upon acquisition. The largest productivity gains predicted by the model accrue to those firms that optimally combine better technology with a larger share of high-skilled workers in production and a better trained workforce. We test these predictions on a longitudinal data set of Spanish manufacturing firms. Combining firm fixed effects with a suitable propensity score weighting estimator, we find empirical evidence that foreign-acquired firms, not only increase their technology level, but also engage in skill upgrading upon acquisition (through both hiring and training). Moreover, we show that these changes are driven by the market size effect, and not by changes in the ownership structure per se. Finally, we reveal a technology-skill complementarity in the data implying that the productivity gains associated with better technology are magnified for firms actively engaging in skill upgrading. Overall, our paper provides strong evidence for the notion that foreign MNEs "inject" skill-biased technological change into their affiliated firms.
\end{abstract}

JEL codes: D22; D24; F23; G34

Keywords: Multinational Enterprises; Mergers and Acquisitions; Skill-biased Technological Change; Worker Training; Productivity

\footnotetext{
${ }^{*}$ We would like to thank Hartmut Egger, Valeria Gattai, Wilhelm Kohler, Philipp Schröder, and Hylke Vandenbussche for helpful comments and discussions. We are grateful to participants at the Aarhus-Kiel Workshop, the Göttingen Workshop on International Economics, the Annual Meeting of the European Trade Study Group in Helsinki, the NOITS 18th Annual Workshop in Helsinki, as well as research seminars at universities in Aarhus, Bayreuth, Milan, and Pamplona. Financial support by the Tuborg Foundation is gratefully acknowledged.

${ }^{\S}$ University of Bayreuth, Department of Law and Economics, Universitätsstr. 30, 95447 Bayreuth, Germany; phone: +4992155 6084; email: michael.koch@uni-bayreuth.de

`Aarhus University, Department of Economics and Business Economics, Fuglesangs Allé 4, Building 2632, 8210 Aarhus V, Denmark; phone: +45 8716 4974; email: msmolka@econ.au.dk
} 


\section{Introduction}

Understanding the effects of foreign direct investment (FDI) and the behavior of multinational enterprises (MNEs) is a core issue in the study of international economics. The increasing availability of detailed micro-level data along with methodological advances in the econometric analysis of these data have made it possible for researchers to go beyond quantifying the aggregate effects of FDI on host countries, and investigate the channels behind important correlations found in aggregate data. A considerable amount of research has been devoted to the effects of foreign acquisitions on the productivity of acquired firms. ${ }^{1}$ In this paper, we investigate the firm-level effects of foreign acquisitions in the Spanish manufacturing sector, and we provide a new angle on the relationship among foreign ownership, technology, and skills. We find causal evidence for substantial skill upgrading within foreign-acquired firms at the same time as we observe enhanced innovation activity, and we demonstrate that higher levels of skills and technology crucially interact with one another in boosting post-acquisition performance. The novelty of our analysis lies in combining exceptionally detailed and direct information on the ownership structure of firms, their foreign market access, their technological innovations, and, most importantly, their efforts to enhance the skills of their workforce through hiring and training.

Our analysis is motivated by the observation that foreign acquisitions can induce upward shifts in the technology level of acquired firms. Foreign-acquired plants in Indonesia, for example, experienced substantial restructuring upon acquisition involving a steep increase in machinery investment (Arnold and Javorcik, 2009). Foreign acquisitions in the Spanish manufacturing sector similarly led to more product and process innovation and adoption of foreign technology (Guadalupe et al., 2012). While the use of superior technology can raise domestic productivity, operating this technology at maximum efficiency might require skills that are not available in the domestic firm upon acquisition. This creates incentives for the domestic firm to acquire these skills, in order to bring the new technology to its full economic potential. The basic argument follows the long-standing idea of skill-biased technological change. Skill-biased technological change reflects a fundamental technology-skill complementarity which implies that shifts in the technology frontier favor the relative productivity of skilled over unskilled labor.

Our paper makes two contributions to the literature on multinational firms and the effects of FDI. First, we develop a theoretical model to formalize the notion that foreign MNEs "inject" skill-biased technological change into their affiliated firms. The issue of skill-biased technological change has long been a primary concern for economists, but previous research on multinational firms has largely neglected its implications for the effects of foreign acquisitions, and investigated changes in technology and skills as if they were separate processes. Our model, in contrast, provides a framework for thinking about how technology and skills interact with one another and how they are both linked to the acquisition event. In addition, our model addresses the important question

\footnotetext{
${ }^{1}$ Differences between foreign-owned and domestically owned firms have been documented in numerous econometric studies. Prominent examples include Aitken and Harrison (1999), Criscuolo and Martin (2009), Javorcik (2004), Ramondo (2009), Sabirianova et al. (2005), and Yasar and Morrison Paul (2007).
} 
how changes in technology and skills jointly affect firm productivity as a result of the acquisition. The second contribution of our paper is to test the implications of our model empirically on Spanish firm-level data. Our main finding is that, in addition to innovating more, foreign-acquired firms take swift action to upgrade the skills of their workforce, with considerable implications for postacquisition performance. In particular, we show that the favorable evolution of productivity in foreign-acquired firms cannot be explained by shifts in the technology level alone, but derive from a concurrent effort to improve technology and enhance workforce skills. Overall, our results provide new insights into the channels through which foreign MNEs generate productivity gains in their acquisition targets.

We begin with a theoretical analysis to describe and explore the mechanism how foreign acquisitions can produce skill-biased technological change. The starting point is the model by Guadalupe et al. (2012) where firms differ in their initial (exogenous) productivity and make an endogenous choice about the level of technology. A key aspect of this model is that foreign-acquired firms choose a higher level of technology because of the role the foreign parent plays in facilitating access to foreign markets. While our model shares this market size effect of foreign ownership, we crucially depart from the assumption in Guadalupe et al. (2012) that labor is a homogeneous factor of production. Instead, we introduce two dimensions of labor heterogeneity which allow focusing on critical interactions between technology and skills. First, we distinguish between two skill typeshigh- and low-skilled labor - and we assume that high-skilled labor is more efficient in solving more complex tasks in the production process, as in Acemoglu and Autor (2011); we also assume that, while both high- and low-skilled labor become more productive through an increase in the technology level of the firm, high-skilled labor will enjoy larger productivity gains than low-skilled labor. ${ }^{2}$ Second, we allow firms to invest in worker training, and thus increase the overall productivity of their workforce regardless of skill type; we also impose a complementarity between technology and worker training similar to Acemoglu (1997). ${ }^{3}$

The focus of our model on endogenous skill decisions of firms and how these interact with firms' technology choices generates several new predictions. First, the market size effect of foreign ownership not only stimulates innovation, but also generates higher returns to worker training. ${ }^{4}$ Moreover, by introducing a complementarity between technology and worker training, investments in both activities will be larger than what they would be in the absence of such complementarity.

\footnotetext{
2 The literature has documented a positive link between the demand for skill and different types of innovation activities. For instance, Akerman et al. (2015) provide evidence that technological change in the form of broadband adoption increases the marginal productivity of skilled workers. Levy and Murnane (1996) and Autor et al. (2003) document a positive link between computers and skill demand. Lewis (2011) shows that investments in automation machinery substituted for the least skilled workers and complements more skilled workers.

${ }^{3}$ Empirical evidence on the complementarity between technology upgrading and worker training can be found in Ichniowski et al. (2007) who show that operating new IT-enhanced capital equipment increases the need for technical and problem-solving skills which firms meet by adopting new human resource practices (e.g. worker training).

${ }^{4}$ Of course, one can think of different channels why foreign-acquired firms innovate more and expand worker training, e.g. (cheaper) access to superior proprietary technology (see Caves, 1996) or lower training costs due to superior management practices (see Bloom and Van Reenen, 2010). While our model can easily incorporate these different channels, we focus on the market size effect here, as we can explicitly address this channel in our empirical analysis.
} 
Secondly, by modeling innovations in such a way that they favor the relative productivity of highskilled labor, our model predicts that firms will hire more high-skilled workers in response to the acquisition, in order to increase their overall production efficiency. And finally, our model predicts that the largest productivity gains will accrue to those firms that optimally combine new and superior technology with suitably trained workers as well as a higher skill intensity in production. This is in sharp contrast to Guadalupe et al. (2012) who attribute all changes in post-acquisition performance to changes in technology.

The predictions of our model are tested on Spanish firm-level data from the Encuesta Sobre Estrategias Empresariales (ESEE) for the period 1998-2013. ${ }^{5}$ A major advantage of using the ESEE data-set is - in addition to its panel structure and time horizon - its breadth and level of detail. ${ }^{6}$ As indicated above, the ESEE survey collects a large and unique set of firm characteristics that are of special importance for the purpose of our analysis: the survey includes information about the ownership structure of firms (foreign versus domestic), their various innovation activities (e.g. process and product innovation), the means by which they access foreign markets (through the foreign parent or through other means), as well as their efforts to enhance the skills of their workforce (e.g. hiring of recent university graduates and expenditures on worker training in various fields). A key challenge in our empirical analysis is to isolate the effects of foreign ownership on technology and skill choices from non-random selection into foreign ownership. To do so and establish causality, we exploit the panel dimension of the data and combine firm fixed effects with a suitable propensity score estimator that takes into account the fact that high-performing firms are more likely to become acquisition targets of foreign MNEs (as predicted by the model and confirmed by the evidence from Spain (see Guadalupe et al., 2012)).

We generate three sets of empirical results. First, we find clear evidence for skill upgrading caused by foreign acquisitions, i.e., we observe considerable upward shifts in various skill-related activities when firms are acquired by foreign MNEs. Specifically, we find a shift in the hiring policy towards fresh university graduates causing the share of high-skilled workers to rise upon acquisition. Moreover, we find a significant increase in worker training, not just overall, but also specifically in those fields that are closely related to the production technology of the firm (such as engineering and IT). Importantly, these actions are taken at about the same time as firms start producing more technological innovations in response to the acquisition. Secondly, we investigate the exact channel behind these results, and demonstrate that skill upgrading is triggered by the market size effect of foreign ownership, and not by foreign ownership per se. Since our data identify precisely which firms rely on their foreign parent in gaining access to foreign markets, we can use this information to clearly discriminate within the group of foreign-acquired firms. As it turns out, skill upgrading (whether through hiring or training) is found just for those firms that use their foreign parent for exporting, but not for other firms. And finally, we demonstrate a complementarity between skills

\footnotetext{
${ }^{5}$ The country and period are well-suited for our analysis as the Spanish economy received sizable inflows of FDI during our sample period. While the stock of inward FDI remained relatively stable at around 10-20\% of GDP during the 1990s, it increased to almost 50\% during the 2000s (UNCTAD FDI database).

${ }^{6}$ Among others, it has been used in various different contexts by Antràs (2015), Delgado et al. (2002), Garicano and Steinwender (2016), Guadalupe et al. (2012), and Kohler and Smolka (2014).
} 
and technology in boosting firm productivity. More precisely, while it is well-known that a firm's productivity level is an increasing function of its technology level, we show that this function is more steeply sloped when the firm engages in skill upgrading through hiring and training. This is consistent with our model and supports our basic argument that technological progress that occurs in relation to foreign acquisitions is - at least in the case of Spain and for the period we investigate -skill biased.

Our paper contributes to a growing literature that tries to, not only identify the causal effect of foreign ownership on productivity, but also pinpoint why exactly foreign-acquired firms might follow a different productivity path than firms remaining in domestic ownership. Important examples in this literature include the above-mentioned papers by Arnold and Javorcik (2009) and Guadalupe et al. (2012). ${ }^{7}$ We contribute to this literature by focusing on (different forms of) skill upgrading within firms, and by emphasizing interactions between technology and skill that have not received much attention in the literature, but which we show to be crucial for understanding post-acquisition performance. Our paper thus sheds new light on the origin of persistent productivity differences across firms within industries (see Syverson, 2011).

Since we investigate skill upgrading in relation to foreign acquisitions, our paper is also related to a broad literature that empirically explores the nexus between foreign acquisitions (or FDI more generally) and the relative demand for skilled labor. Influential studies at the industry level are Blonigen and Slaughter (2001), Fabbri et al. (2003), and Taylor and Driffield (2005), while more recent papers use firm-level data, e.g. Almeida (2007) and Hijzen et al. (2013). Our understanding is that this literature has produced rather mixed results and often fails to find a significant association between skills and FDI. Our contribution is to use a rich survey data set that allows us to study within-firm adjustments in a set of skill-related activities that are difficult or impossible to observe in other data sets and thus have escaped the attention of other studies. While existing studies measure the demand for skilled labor focusing on workers' schooling or occupations, we use detailed information not only on the hiring practices of firms (e.g. hires of newly graduated workers), but also on worker training (in various different fields). ${ }^{8}$

Finally, by providing evidence on the relationship among foreign ownership, innovation, and skill upgrading, our paper contributes to the influential and extensive literature on skill-biased technological change. Excellent reviews of this literature can be found in Acemoglu (2003), Bond and Van Reenen (2007), and Goldin and Katz (2007). One potential limitation in this literature is that skill-biased technological change is difficult to observe directly, and so the evidence usually derives from aggregate data, i.e., industry- or country-level data. This ignores substantial withinindustry variation across firms as well as endogeneity in technology and skill choices at the firm level (see Bøler, 2015). More recent studies use exogenous variation in the availability of new

\footnotetext{
${ }^{7}$ A recent paper by Stiebale (2016) provides evidence on the effects on both acquiring and acquired firms in Europe. Girma et al. (2015) use Chinese data to study not only the direct effects of foreign ownership on the productivity of the acquired firm, but also spillover effects to other firms.

${ }^{8}$ There is a different literature on the effects of foreign ownership that explores a wage premium in foreign-owned firms for a given occupation or skill level using linked employer-employee data (see e.g. Heyman et al., 2007; Huttunen, 2007).
} 
technology - e.g. broadband internet as in Akerman et al. (2015) - to test whether and to what extent technological change is skill biased. By exploiting within-firm variation in technology and skills triggered by changes in ownership structure from domestic to foreign, we provide a novel and tangible piece of evidence, at the firm level, that supports the notion that technological progress is skill biased.

The remainder of our paper proceeds as follows. In Section 2 we develop a simple model of foreign ownership and skill-biased technological change. In Section 3 we describe our data set and the sample we use. In Section 4 we present our empirical analysis and the main findings. Section 5 concludes.

\section{Model}

Consider an industry in which firms produce differentiated varieties and sell their output in a monopolistically competitive market. Firms face an iso-elastic demand function of the form

$$
q(v)=A_{m} p(v)^{-\sigma}
$$

where $q(v)$ and $p(v)$ denote demand and price for variety $v$, respectively, $\sigma>1$ measures the (constant) elasticity of substitution between any two varieties, and $A_{m}$ is a measure of market size with $m \in(d, f) .{ }^{9}$ While firms face no restrictions in serving the domestic market, serving the foreign market requires access to a specific distribution channel that can only be granted by a foreign parent company. Thus, while firms in foreign ownership have access to both the domestic and the foreign market, firms in domestic ownership are confined to the domestic market, i.e., $A_{f}>A_{d}$.

Production of a specific variety $v$ requires the performance of a continuum of tasks (for convenience normalized to the unit interval). Similarly to Acemoglu and Autor (2011), we use a simple Cobb-Douglas production function to formalize the assembly of tasks in the production of variety $v$ :

$$
x(v)=\phi(v) \exp \left[\int_{0}^{1} \ln x(v, i) d i\right]
$$

where $\phi(v)$ is an (exogenous) productivity parameter and $x(v, i)$ is the production level of task $i$ in firm $v$ producing total firm output $x(v)$.

To model skill-biased technological change and highlight the link between foreign ownership, innovation, and skill upgrading, we assume that output at the task level, $x(v, i)$, depends on the task, the skill, and the technology. More specifically, we assume that tasks can be ordered according to their complexity where a higher index $i$ reflects higher complexity. High-skilled workers have a

\footnotetext{
${ }^{9}$ Maximizing a constant-elasticity-of-substitution (CES) utility function of the form $U=\left[\int_{v \in V} q(v)^{\frac{\sigma-1}{\sigma}} d v\right]^{\frac{\sigma}{\sigma-1}}$ subject to a consumer's budget constraint $E=\int_{v \in V} p(v) q(v) d v$, where $E$ are total expenditures on the set of available varieties $V$, gives the demand function in Eq. (1) with $A \equiv E P^{\sigma-1}$ and $P=\left[\int_{v \in V} p(v)^{1-\sigma} d v\right]^{\frac{1}{1-\sigma}}$ denoting the price index.
} 
productivity advantage in the performance of complex tasks, i.e., we assume a complementarity between the complexity of a task and the skill of a worker when determining labor productivity at the firm-task level (similar to Acemoglu and Autor, 2011). Moreover, the productivity advantage of high-skilled workers is increasing in the level of technology. Thus, high-skilled workers have a comparative advantage over their low-skilled coworkers in using modern, more advanced technology. Finally, firms can raise the productivity of high- and low-skilled workers alike, by training them in performing tasks more efficiently. Importantly, and as will become evident below, we assume a complementarity between technology and worker training, generating incentives for firms to provide worker training whenever they adopt new and more advanced technology. ${ }^{10}$

We omit variety index $v$ from now on and assume that task output is determined according to the following linear homogeneous production function:

$$
x(i)=\beta(\lambda, \tau)[l(i)+\alpha(\lambda, i) h(i)],
$$

where $l(i)$ and $h(i)$ denote the quantities of low- and high-skilled labor, respectively, and $\alpha(\lambda, i)$ captures the productivity advantage of high-skilled workers in the production of task $i$ as a function of the firm's technology level $\lambda$. The function $\beta(\lambda, \tau)$, on the other hand, is an overall productivity shifter which applies equally to both high- and low-skilled labor, and which depends, not only on the firm's technology level $\lambda$, but also on the level of worker training $\tau$.

To capture the complementarity and the link between task-specific complexity and technology choice, we impose that $\alpha(\lambda, i)$ is a twice differentiable, strictly increasing and convex function of $i$, and that it is strictly increasing in the technology level $\lambda$. For concreteness, and to ensure that the analysis remains tractable, we set $\alpha(\lambda, i)=\exp [\lambda i]$ for all $i \in[0,1]$. This implies that a high-skilled worker assigned to the least complex task is as productive as her low-skilled coworker, whatever the technology level, since her specific skills are not required for performing the respective task. Things are different in the case of a more complex task, where the higher skill level generates an absolute productivity advantage that is increasing in the technology level of the firm. Importantly, new technology (captured by a rise in $\lambda$ ) will disproportionately favor more complex tasks, in the sense that the productivity advantage of high-skilled labor will increase more strongly in more complex tasks than in less complex tasks.

Finally, to formalize the complementarity between the level of technology and worker training, we set $\beta(\lambda, \tau)=\lambda \tau$ and assume that $\lambda \geq 1$ and $\tau \geq 1$. This implies that a change in technology giving rise to a higher value of $\lambda$ will magnify the productivity gains arising from worker training.

\footnotetext{
${ }^{10}$ Koch (2016) presents a related but more restrictive framework in which firms endogenously assign high- and lowskilled workers to tasks that differ in their complexity, but without considering endogenous investments in innovation and training, as we do here. In contrast to our model, the model in Koch (2016) allows studying how trade liberalization leads to skill adjustments within firms through a general equilibrium effect.
} 


\subsection{Firms' optimization problem}

After entering the industry and learning about the (exogenous) firm productivity $\phi$, firms maximize their profits according to a four-stage optimization problem. ${ }^{11}$ In the first step, firms choose the optimal level of technology, comparing the productivity gains due to a higher $\lambda$ with the costs of innovation $C(\lambda)=\lambda^{\epsilon_{0}}$. In the second step, firms decide upon the optimal level of worker training, comparing the associated productivity gains with the costs of training $C(\tau)=\tau^{\epsilon_{1}}$. In the third step, firms determine the optimal allocation of skills to tasks and, thus, the range of tasks performed by low- and high-skilled workers, respectively, by comparing the productivity advantage of high-skilled workers with the skill premium $\omega \equiv w_{h} / w_{l}$ (where $w_{j}, j=l, h$ are the costs of one unit of labor of type $j$ ). In the fourth and final step, firms choose output at the task level, which is equivalent to determining the task-level employment for a given skill assignment and a given technology and training choice. We solve the model by backward induction.

\subsubsection{Optimal employment at the task level - stage 4}

For a given technology and training choice and a given assignment of workers to tasks, firms set task-level output $x(i)$ to maximize their profits

$$
\pi=p x-\int_{0}^{1} x(i) c_{k}(i) d i-C(\lambda)-C(\tau)-f
$$

subject to (1) and (2). In this equation, $c_{k}(i)$ denotes the unit costs of a firm performing task $i$ with the preassigned skill type $k=l, h$ and $f$ denotes fixed costs required to manage the firm, organize the production process, set up a production plant, etc. ${ }^{12}$ Due to the technology in Eq. (2) being of the Cobb-Douglas type and the special case of each task entering the production function symmetrically, cost shares are the same for all tasks. To be more specific, substitution of (1) into the first-order condition $\partial \pi / \partial x(i)=0$ gives

$$
\frac{\sigma-1}{\sigma} p x=x(i) c_{k}(i) \quad \forall i \in[0,1]
$$

A direct implication of the identical cost shares is that the firm employs the same number of workers of a given skill type in all tasks performed by workers of this skill type, i.e., $w_{l} l(i)=w_{l} l$ and/or $w_{h} h(i)=w_{h} h$.

\footnotetext{
${ }^{11}$ Notice that the firm's profits will be maximized regardless of whether the owner of the firm is located in the domestic or the foreign economy.

${ }^{12}$ As we do not solve the model in general equilibrium, we keep the analysis as simple as possible and do not specify in which units the costs of technology, the costs of worker training and the fixed costs are paid (in units of low-skilled labor, high-skilled labor or any numéraire good). The results of the model remain unaffected as long as the unit costs are not firm specific.
} 


\subsubsection{Optimal skill intensity - stage 3}

With the optimal amount of workers for each task $i$ at hand we can proceed and determine the optimal range of tasks that are performed by the two skill types. Ordering tasks according to their complexity allows us to define a unique threshold task $z \in(0,1)$ where the firm is indifferent between hiring low-skilled or high-skilled workers (given relative wages $\omega=w_{h} / w_{l}$ ). In other words, the unit costs of performing task $z$ are the same irrespective of the assigned skill type $k=l, h$, which implies $c_{l}(z)=c_{h}(z)$ or, equivalently, $\omega=\exp [\lambda z]$ and hence

$$
z(\lambda)=\frac{\ln \omega}{\lambda}
$$

Due to the relative advantage of high-skilled workers in performing more complex tasks, it follows that low-skilled workers will be assigned to all tasks $i<z(\lambda)$, while high-skilled workers will be assigned to all tasks $i \geq z(\lambda) .{ }^{13}$ Having solved the firm's assignment problem, we are now able to compute a firm's skill intensity, which we denote by $s(\lambda)$. We define $L=\int_{0}^{z(\lambda)} l(i) d i=z(\lambda) l$ and $H=\int_{z(\lambda)}^{1} h(i) d i=[1-z(\lambda)] h$ as firm's total low-skilled and high-skilled variable labor input, respectively, and note that $w_{l} l(i)=w_{l} l$ and $w_{h} h(i)=w_{h} h$ from above, so that a firm's skill intensity is given by

$$
s(\lambda) \equiv \frac{H}{L}=\frac{1-z(\lambda)}{z(\lambda) \exp [\lambda z(\lambda)]} \stackrel{(6)}{=} \frac{1-z(\lambda)}{z(\lambda) \omega} .
$$

From inspection of (6) and (7) one can immediately see that technology upgrading, captured by an increase in $\lambda$, leads to an increase in a firm's skill intensity $s(\lambda)$. A higher level of technology increases the comparative advantage of high-skilled workers in the performance of complex tasks and firms respond to this by hiring high-skilled workers and assigning them to a broader range of tasks (so that $z(\lambda)$ decreases). ${ }^{14}$

Having determined the threshold task $z$ we can combine Eqs. (2) and (3) to rewrite firm output as

$$
x=\phi \varphi(z, \lambda, \tau) \exp \left[\int_{0}^{z(\lambda)} \ln l(i) d i+\int_{z(\lambda)}^{1} \ln h(i) d i\right]
$$

\footnotetext{
${ }^{13}$ Since $z(\lambda)$ is restricted to values between zero and one, we allow $\lambda$ to vary within the interval $[\ln \omega, \infty)$.

${ }^{14}$ The positive link between innovation and a firm's skill intensity is, of course, a direct implication of our assumption that the productivity advantage of high-skilled workers is increasing in $\lambda$. Alternatively we could make use of a more general functional form for $\alpha(\lambda, i)$, e.g. $\alpha(\lambda, i)=\exp \left[\lambda^{\kappa} i\right]$, where the parameter $\kappa$ determines the sign of the relation between innovation and the productivity advantage of high-skilled workers. If $\kappa<0$ ( $>0$ ), innovation reduces (increases) the comparative advantage of high-skilled workers, and firms will respond by lowering (raising) their skill intensity. If $\kappa=0$, innovation is skill neutral and does not affect the optimal allocation of skills to tasks. We decided against the more general functional form as a sizable number of studies have documented the advantage of highskilled workers in using more advanced technology (see the literature review in footnote 2). Moreover, our empirical analysis below demonstrates that foreign-acquired firms increase their skill intensity upon acquisition, in line with the parameterization we use in the text.
} 
where $\varphi(z, \lambda, \tau)$ is defined as

$$
\varphi(z, \lambda, \tau) \equiv \exp \left[\int_{0}^{1} \ln \beta(\lambda, \tau) d i+\int_{z(\lambda)}^{1} \ln \alpha(\lambda, i) d i\right]=\lambda \tau \exp \left[\lambda \frac{1-z(\lambda)^{2}}{2}\right] .
$$

According to (8), firm productivity consists of two parts: an exogenous baseline productivity $\phi$ and an endogenous productivity term $\varphi(z, \lambda, \tau)$, which varies with the technology choice, the implied assignment of skills to tasks, and the level of worker training. From $\varphi_{\lambda}>0, \varphi_{\tau}>0$, and $z_{\lambda}<0$ it follows that firms can raise their productivity through investments in technology and worker training, as well as through the assignment of a larger range of tasks to high-skilled workers. More specifically, productivity gains can arise from an increase in $\lambda$, and they are clearly stronger if firms additionally provide worker training $\left(\varphi_{\lambda \tau}>0\right)$ and hire new high-skilled workers by reducing $z(\lambda)$. However, upgrading the firm's technology, providing more worker training, and producing with a higher skill intensity raises the costs of a firm and is therefore not necessarily beneficial. How the profit-maximizing levels of worker training and technology are determined is now discussed in the solution to stages 2 and 1.

\subsubsection{Optimal level of worker training - stage 2}

To derive the optimal level of worker training, we first compute the optimal price set by a firm: ${ }^{15}$

$$
p=\frac{\sigma}{\sigma-1} \frac{w_{l}^{z(\lambda)} w_{h}^{1-z(\lambda)}}{\phi \varphi(z, \lambda, \tau)} \stackrel{(6)}{=} \frac{\sigma}{\sigma-1} \frac{w_{h}}{\phi \tau \widetilde{\lambda}},
$$

where

$$
\widetilde{\lambda} \equiv \lambda \omega^{z(\lambda)} \exp \left[\lambda \frac{1-(\ln \omega / \lambda)^{2}}{2}\right]=\lambda \exp \left[\frac{1}{2} \lambda+\frac{(\ln \omega)^{2}}{2 \lambda}\right]
$$

Noting that firm revenues $r$ are given by $r=p x$ and accounting for (1) and (10), we can write profits as

$$
\pi=\frac{A_{m}}{\sigma}\left[\frac{\sigma}{\sigma-1} \frac{w_{h}}{\phi \tau \widetilde{\lambda}}\right]^{1-\sigma}-\lambda^{\epsilon_{0}}-\tau^{\epsilon_{1}}-f
$$

\footnotetext{
${ }^{15}$ We first integrate (5) over the unit interval, which shows that prices are set as a constant markup over variable unit costs: $p=[\sigma C] /[(\sigma-1) x]$, where $C \equiv \int_{0}^{1} x(i) c_{k}(i) d i$ are a firm's total variable labor costs. Using Eq. (7) we can rewrite a firm's total variable labor costs as $C=\left[w_{l} L / H+w_{h}\right] H=w_{h} h$ and this firm's output as $x=$ $\phi \varphi(\cdot)\{[(1-z(\lambda)) / z(\lambda)] L / H\}^{z(\lambda)} h=\phi \varphi(\cdot) \omega^{z(\lambda)} h$. Hence, the variable unit costs of this firm are given by $C / x=$ $w_{l}^{z(\lambda)} w_{h}^{1-z(\lambda)} /[\phi \varphi(\cdot)]$, which is equal to the marginal costs of the respective producer. Constant markup pricing therefore gives (10).
} 
Maximizing profits with respect to training expenditures, setting the respective equation equal to zero and solving for $\tau$, we can compute

$$
\tau=\left\{\frac{\sigma-1}{\sigma} \frac{A_{m}}{\epsilon_{1}}\left[\frac{\sigma-1}{\sigma} \frac{\phi \tilde{\lambda}}{w_{h}}\right]^{\sigma-1}\right\}^{\frac{1}{\epsilon_{1}-\sigma+1}}
$$

Eq. (13) determines the optimal level of worker training as a function of initial productivity $\phi$, market size $A_{m}$, technology level $\lambda$, and other model parameters. Provided that training costs are sufficiently convex, such that $\epsilon_{1}>\sigma-1$, we have $\tau_{\phi}>0$ and $\tau_{A_{m}}>0$, i.e., firms with higher initial productivity and access to larger markets provide more training. Furthermore, we have $\tilde{\lambda}_{\lambda}>0$ and thus $\tau_{\lambda}>0$. Hence, producing with a more advanced technology will prompt the firm to raise investment in worker training.

\subsubsection{Optimal level of technology - stage 1}

Substituting the optimal level of worker training in Eq. (13) into the profit function, we can rewrite profits solely as a function of the level of technology and exogenous model parameters:

$$
\pi=\frac{\epsilon_{1}-\sigma+1}{\sigma-1}\left[\frac{\sigma-1}{\sigma} \frac{A_{m}}{\epsilon_{1}}\right]^{\frac{\epsilon_{1}}{\epsilon_{1}-\sigma+1}}\left[\frac{\sigma-1}{\sigma} \frac{\phi}{w_{h}}\right]^{\frac{\epsilon_{1}(\sigma-1)}{\epsilon_{1}-\sigma+1}} \widetilde{\lambda}^{\frac{\epsilon_{1}(\sigma-1)}{\epsilon_{1}-\sigma+1}}-\lambda^{\epsilon_{0}}-f .
$$

Maximizing profits in Eq. (14) with respect to $\lambda$ and setting the respective equation equal to zero gives:

$$
\left[\frac{\sigma-1}{\sigma} \frac{A_{m}}{\epsilon_{1}}\right]^{\frac{\epsilon_{1}}{\epsilon_{1}-\sigma+1}}\left[\frac{\sigma-1}{\sigma} \frac{\phi}{w_{h}}\right]^{\frac{\epsilon_{1}(\sigma-1)}{\epsilon_{1}-\sigma+1}}{\widetilde{\lambda_{1}(\sigma-1)}}^{\frac{\epsilon_{1}-\sigma+1}{\epsilon_{1}}}\left[\frac{1}{\lambda}+\frac{1}{2}-\frac{1}{2}\left(\frac{\ln \omega}{\lambda}\right)^{2}\right]=\epsilon_{0} \lambda^{\epsilon_{0}-1} .
$$

Provided that the costs of innovation are sufficiently convex, $\pi_{\lambda}$ in Eq. (15) implicitly determines the optimal level of technology as a function of initial productivity, market size, and other model parameters. ${ }^{16}$ Using the implicit function theorem, we can compute $d \lambda / d \phi=-\pi_{\lambda \phi} / \pi_{\lambda \lambda}>0$. Hence, larger and more productive firms will produce with a higher technology level compared to their less productive competitors within the same industry.

\subsection{Impact of foreign ownership}

Having solved a firm's four-stage optimization problem, we are now equipped to discuss how foreign ownership affects the relevant choice variables of the firm. Specifically, the new owner compares the potential profit income before and after the acquisition and decides upon the optimal level

\footnotetext{
${ }^{16}$ To see this we can compute $\pi_{\lambda \lambda}=B \tilde{\lambda}^{\frac{\epsilon_{1}(\sigma}{\epsilon_{1}-\sigma+1}}\left\{\frac{\epsilon_{1}(\sigma-1)}{\epsilon_{1}-\sigma+1}\left[2 \lambda+\lambda^{2}-(\ln \omega)^{2}\right]^{2}+4 \lambda\left[(\ln \omega)^{2}-\lambda\right]\right\}-4 \epsilon_{0}\left(1+\epsilon_{0}\right) \lambda^{\epsilon_{0}+2}$, with $B \equiv \epsilon_{1}\left[\frac{\sigma-1}{\sigma} \frac{A_{m}}{\epsilon_{1}}\right]^{\frac{\epsilon_{1}}{\epsilon_{1}-\sigma+1}}\left[\frac{\sigma-1}{\sigma} \frac{\phi}{w_{h}}\right]^{\frac{\epsilon_{1}(\sigma-1)}{\epsilon_{1}-\sigma+1}}$. Hence, if $\epsilon_{0}$ is sufficiently large (relative to all other model parameters), the costs of innovation (right hand side of Eq. (15)) are increasing faster then the respective revenue gains (left hand side of Eq. (15)) and thus $\pi_{\lambda \lambda}<0$.
} 
of technology, the optimal level of worker training, as well as the optimal skill intensity of the firm. Importantly, the change from domestic to foreign ownership can influence the technology and training decisions directly through a market size effect, i.e., an increase in $A_{m}$ from $A_{d}$ to $A_{f}$, if the acquired firm uses the foreign parent as a means to access the foreign market. ${ }^{17}$ In particular, there will be a positive effect on the investment decisions of the acquired firm according to Eq. (15) and $d \lambda / d A_{m}=-\pi_{\lambda A_{m}} / \pi_{\lambda \lambda}>0$ since larger revenues from serving foreign consumers raises the incentives to innovate. From inspection of Eq. (13) we can see that firms will also increase their training expenditures due to a direct market size effect, $\tau_{A_{m}}>0$, as well as the complementarity between training and technology, $\tau_{\lambda}>0$. In addition, firms will hire high-skilled workers and assign them to a broader range of tasks according to Eq. (6). ${ }^{18}$

The complementarity between technology upgrading and skill upgrading along with the respective productivity gains are illustrated in Figure 1. The left panel of Figure 1 illustrates productivity gains due to changes in the productivity advantage schedule $\alpha(\cdot)$ for high-skilled workers (keeping training expenditures constant), while the right panel illustrates productivity gains arising from technology upgrading and increased worker training (keeping the productivity advantage of high-skilled workers and, thus, $z$ constant). For a given technology and optimal skill intensity the realized productivity advantage of high-skilled workers is captured by area $A$ in the left panel of Figure 1. New investments in technology lead to an increase in $\lambda$ (to $\lambda^{\prime}$ ) and thus rotate the productivity advantage curve for high-skilled workers counter-clockwise in task 0. For a given share of tasks performed by high-skilled workers, i.e., for a given $z$, the productivity gains of high-skilled workers due to better technology are captured by area $B$. However, as the productivity advantage of high-skilled workers has also increased in tasks that are less complex than the threshold task, firms will increase their skill intensity by reducing $z$ (to $z^{\prime}$ ) and thus realize productivity gains captured by area $C$. Moreover, the new technology has a direct positive impact on the efficiency of all workers and raises - due to a complementarity effect - the incentives for firms to invest in worker training. These productivity gains are captured in the right panel of Figure 1, where the areas $D$ and $E$ depict the productivity gains from innovation and worker training, respectively.

Taking stock, the model predicts that upon acquisition domestic firms will upgrade their production technology and train their workers, provided they get access to foreign markets through the foreign parent firm (market size effect). Both activities will lead to productivity gains. However, additional productivity gains will materialize if firms use the new technology more efficiently, by investing more in worker training than what is commanded by the market size effect alone, as well

\footnotetext{
${ }^{17}$ Another direct effect not stressed in our model could be that it becomes less costly for the acquired firm to engage in skill upgrading, for example because the foreign parent provides the acquired firm with worker training at a price lower than the market rate, such that the cost (shape) parameter $\epsilon_{1}$ is lower for foreign-owned than for domestically owned firms. Additionally, the foreign owner may provide access to better or less expensive technology, which can be captured by a decrease in $\epsilon_{0}$ and thus the marginal costs of innovation. However, as we are able to explicitly address the market size effect in our empirical analysis, we focus on this channel here.

${ }^{18}$ Due to the complementarity among technology upgrading, skill upgrading, and initial firm productivity, the gains arising from an increase in market size are larger for firms with higher initial productivity. Hence, as in Guadalupe et al. (2012), foreign companies have an incentive to acquire the more productive domestic firms, rather than the less productive ones. This creates a selection problem that we address in the empirical analysis.
} 
as by hiring high-skilled workers and assigning them to a broader range of tasks.

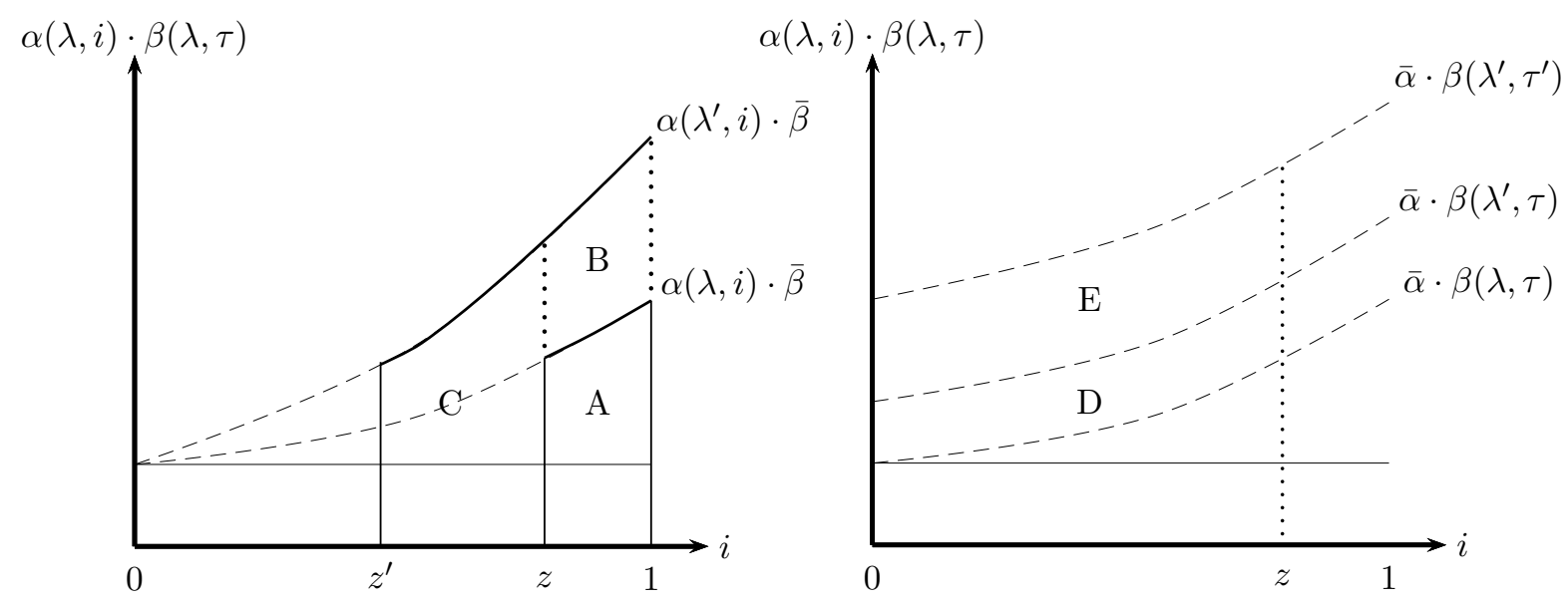

Figure 1: Productivity gains - innovation, skill intensity, and worker training

\section{Data}

The data we use in our empirical analysis come from the Encuesta Sobre Estrategias Empresariales (ESEE) provided by the SEPI foundation in Madrid. The ESEE is an annual survey covering roughly 1,900 Spanish manufacturing firms each year and collecting unusually rich information on strategic firm decisions along with key items of firms' balance sheets as well as profit and loss statements. What makes the ESEE data especially interesting for our analysis is that it does not only record the ownership of the firm (foreign vs. domestic), but also specific productivity-enhancing actions taken by the firm aimed at upgrading both the skills of its workforce and its production technology. In the following we provide details on the specific information we exploit in our analysis.

First of all, the ESEE data provides detailed information that allows computing the productivity of firms. In addition to labor productivity, which we define as real value added per effective working hour, we use the estimation routine developed by Olley and Pakes (1996) to estimate total factor productivity at the firm level. An important advantage of our data set is that it provides firmlevel information on price changes over time both for inputs in the production process and for output. This reduces endogeneity concerns due to heterogeneity in the evolution of input and output prices across firms, which plague the estimation of total factor productivity in many firmlevel data sets (see e.g. De Loecker, 2007). Secondly, the survey data contains direct information on firms' innovation activities and thus technology upgrading. The variables we use are identical to the ones used in Guadalupe et al. (2012), i.e. process innovation (new machines; new methods of organizing production; both new machines and new methods), product innovation, and assimilation of foreign technologies, which are all dummy variables indicating whether the firm carried out the respective activity in a given year. Thirdly, the ESEE data provides explicit information on how 
firms access foreign markets, as the survey asks firms if they use the foreign parent as a distribution channel for their exports.

Finally, and most importantly for our study, we need information on firms' efforts to enhance the skills of their workforce, in order to investigate how changes in ownership affect the demand for skill, and to explore the joint effects of both technology and skill upgrading on firm productivity. Besides skill intensity (the share of workers with a five-year university degree) the survey provides direct information on firms' hiring practices (hiring of recent university graduates; hiring of workers with R\&D experience) and training expenditures in various categories (training in engineering; IT; language; marketing; and other). This has two main advantages. First, in contrast to the received literature, we can study two different margins through which skill upgrading may take place, viz. an increase in the formal education of new hires and an increase in the training workers receive while employed. Second, a firm's actual decisions related to the skills of its workforce might indicate important changes in the firm's human resources strategy that are not reflected in standard and arguably imperfect measures of skill intensity. We therefore believe that our empirical analysis importantly complements existing evidence on the effects of FDI and foreign ownership on skill upgrading.

The sample we use is an unbalanced panel of more than 3,300 different firms over the period 19982013. The initial sampling of the data in 1990 (the first year of the survey) had a two-tier structure, combining exhaustive sampling of firms with more than 200 employees and stratified sampling of firms with 10-200 employees. In the years after 1990, special efforts have been devoted to minimizing the incidences of panel exit as well as to including new firms through refreshment samples aimed at preserving a high degree of representativeness for the manufacturing sector at large. ${ }^{19}$ The data distinguishes between 20 different industries at the 2-digit level of the NACE Rev. 2 classification and six different size groups defined by the average number of workers employed during the year (10-20; 21-50; 51-100; 101-200; 201-500; >500); combinations of industries and size groups serve as strata in the stratification. We express all value variables in constant 2006 prices using firmlevel price indexes constructed from the survey data (where possible) or industry-level price indexes derived from the Spanish Instituto Nacional de Estadística (INE).

We define a firm as foreign owned if a foreign company owns more than 50 percent of its capital. Among all the firms included in our data, 86.2 percent are owned domestically when they first appear in the sample, while 13.8 percent are foreign owned. ${ }^{20}$ We exclude the latter group of firms and instead restrict our sample to potential acquisition targets, i.e., those firms that are initially domestic. Among these firms, 97 percent remain domestic throughout the whole period of analysis, while 3 percent become foreign owned. ${ }^{21}$

\footnotetext{
${ }^{19}$ For details see https://www.fundacionsepi.es/investigacion/esee/en/spresentacion.asp (accessed on May 19, 2017).

${ }^{20} 3.2$ percent of all the firms included in our data are foreign owned by more than zero, but less than 50 percent, when they first appear in the sample, and thus classified as domestically owned. We have checked that excluding these firms from our analysis leaves our empirical results unchanged.

${ }^{21} \mathrm{~A}$ small number of domestic firms report changes in the share of capital owned by a foreign company from zero to between 25-50\%. Including these firms in the group of foreign-acquired firms does not affect our empirical results
} 
Table 1: Productivity, skill, and technology variables

\begin{tabular}{|c|c|c|c|}
\hline & Domestic & Foreign & Observations \\
\hline \multicolumn{4}{|l|}{ Productivity } \\
\hline Labor productivity & $\begin{array}{c}2.968 \\
(0.671)\end{array}$ & $\begin{array}{c}3.415 \\
(0.652)\end{array}$ & 23,224 \\
\hline Total factor productivity & $\begin{array}{c}12.66 \\
(1.897)\end{array}$ & $\begin{array}{c}14.80 \\
(1.627)\end{array}$ & 22,697 \\
\hline \multicolumn{4}{|l|}{$\underline{\text { Skill-related variables }}$} \\
\hline Hires of recent university graduates & $\begin{array}{c}0.170 \\
(0.375)\end{array}$ & $\begin{array}{c}0.413 \\
(0.493)\end{array}$ & 23,474 \\
\hline Training engineering & $\begin{array}{c}0.171 \\
(0.377)\end{array}$ & $\begin{array}{c}0.486 \\
(0.500)\end{array}$ & 19,272 \\
\hline Training IT & $\begin{array}{c}0.157 \\
(0.363)\end{array}$ & $\begin{array}{c}0.403 \\
(0.491)\end{array}$ & 19,270 \\
\hline Training language & $\begin{array}{c}0.178 \\
(0.383)\end{array}$ & $\begin{array}{c}0.585 \\
(0.493)\end{array}$ & 19,271 \\
\hline Training marketing & $\begin{array}{c}0.091 \\
(0.287)\end{array}$ & $\begin{array}{c}0.238 \\
(0.426)\end{array}$ & 19,272 \\
\hline Training other & $\begin{array}{c}0.255 \\
(0.436)\end{array}$ & $\begin{array}{c}0.554 \\
(0.498)\end{array}$ & 19,279 \\
\hline \multicolumn{4}{|l|}{ Technology-related variables } \\
\hline Process innovation: New machines & $\begin{array}{c}0.123 \\
(0.328)\end{array}$ & $\begin{array}{c}0.162 \\
(0.369)\end{array}$ & 23,474 \\
\hline Process innovation: New methods of organizing production & $\begin{array}{c}0.043 \\
(0.204)\end{array}$ & $\begin{array}{c}0.063 \\
(0.243)\end{array}$ & 23,474 \\
\hline Process innovation: Both new machines and new methods & $\begin{array}{c}0.112 \\
(0.315)\end{array}$ & $\begin{array}{c}0.216 \\
(0.412)\end{array}$ & 23,474 \\
\hline Product innovation & $\begin{array}{c}0.186 \\
(0.389)\end{array}$ & $\begin{array}{c}0.269 \\
(0.444)\end{array}$ & 23,474 \\
\hline Assimilation of foreign technologies & $\begin{array}{c}0.095 \\
(0.293)\end{array}$ & $\begin{array}{c}0.222 \\
(0.418)\end{array}$ & 7,547 \\
\hline
\end{tabular}

Notes: This table shows means and standard deviations (in parentheses) of productivity, skill, and technology variables by ownership status of the firm (domestically owned versus foreign owned). The number of observations reported in the final column sums across both domestically owned and foreign-owned firms. The sample spans the years 1998-2013 and is restricted to firms that are owned domestically in the first year they enter the sample. Labor productivity is the natural log of real value added per effective working hour. Total factor productivity (TFP) is the natural $\log$ of TFP estimated by the Olley and Pakes (1996) estimation routine. Hires of recent university graduates is a dummy variable indicating whether the firm hired recent university graduates in a given year. Training engineering, training IT, training language, training marketing, and training other are all dummy variables indicating whether the firm reported positive expenditures on external training in the respective training category in a given year (training other is a residual category capturing any type of training not falling into any of the other categories). The three process innovation variables (new machines; new methods of organizing production; both new machines and new methods), product innovation, and assimilation of foreign technologies (available every four years) are all dummy variables indicating whether the firm carried out the respective activity in a given year.

Source: Authors' computations based on ESEE data.

In Table 1 we pool the data across all years and then sort observations into groups of domestic

in any significant way. 
and foreign ownership, respectively. ${ }^{22}$ We find considerable differences between the two groups, not just in measured productivity, but also in various skill and technology-related activities that importantly determine (future) productivity, but which are rarely observed in firm-level data sets. The fact that foreign-owned firms are more likely than domestically owned firms to carry out activities related to process innovation, production innovation, and the assimilation of foreign technologies has been the focus of Guadalupe et al. (2012). However, the differences in the skill-related activities, which are the focus of our analysis, are equally remarkable. Among the domestically owned firms, for example, 17 percent report hiring of recent university graduates, and the same number report training in language skills, while these numbers for foreign-owned firms are 41 and 49 percent, respectively. Identifying the causal effect of foreign ownership on these skill-related activities is one of the main goals in our empirical analysis.

\section{Empirical analysis}

Our empirical analysis comes in three steps. First, we estimate the effect of foreign ownership on skill upgrading. Second, we test the market size effect associated with foreign ownership. And finally, we estimate the productivity effects when firms engage in both skill and technology upgrading simultaneously.

\subsection{The effect of foreign ownership on skill upgrading}

We begin by investigating whether firms that become foreign owned engage in skill upgrading. In our theoretical model firms do so through two margins. The first is an increase in the number of high-skilled workers (captured by a decrease in $z$ ). The second margin is an increase in worker training (captured by an increase in $\tau$ ).

In our model the response to the acquisition derives from a direct as well as an indirect effect. The direct effect is the market size effect associated with foreign ownership. It arises because a better trained workforce allows the acquired firm to enjoy disproportionately greater benefits due to a larger market size. The indirect effect, on the other hand, derives from the technology-skill complementarity in our model. Because operating a new and superior technology at maximum efficiency requires a more skilled workforce, acquired firms have an incentive to increase the number of high-skilled workers as well as to intensify worker training whenever they upgrade their production technology in response to the acquisition. In the remainder of this section we aim to demonstrate that acquired firms do exactly this: they hire more high-skilled workers and at the same time they increase worker training.

While the ESEE data include detailed information on worker training on a yearly basis, this is not the case for a firm's number of high-skilled workers. Instead we have information on whether the firm hired recent university graduates in any given year. This allows us to construct a measure of

\footnotetext{
${ }^{22}$ In Table A.1 in the Appendix we provide descriptive statistics on further variables we employ in our empirical analysis.
} 
the stock of high-skilled workers as: $h_{i t}=\sum_{j=t_{0}}^{t} h_{i j}$, where $h_{i j}$ is a $0 / 1$ indicator for hiring of recent university graduates and $t_{0}$ is the year the firm enters our sample. ${ }^{23}$ Importantly, a firm's number of high-skilled workers at any point in time $t$ is a function of the history of high-skilled workers entering and leaving the workforce, and thus, other things held constant, increasing in $h_{i t}$. The stock of high-skilled workers at time $t_{0}$ (i.e., when the firm enters our sample) will be controlled for through firm fixed effects in the estimation. Thus, the effect of foreign ownership that we identify in our empirical model will be a shift in the firm's hiring policy towards fresh university graduates, or, similarly, an increase in the number of high-skilled workers after the acquisition. ${ }^{24}$

The information on worker training in our data is available from 2001 onwards and distinguishes five different types: engineering, IT, marketing, language, and other (a residual category). This allows us to investigate whether acquired firms increase worker training, not just overall, but also specifically in those categories that are closely related to a firm's production technology (viz. engineering and IT). Since past training expenditures contribute positively to the stock of knowledge available in a firm, we proceed as with the firm's skill intensity and construct a measure of the (training-related) stock of knowledge as: $\tau_{i t}=\sum_{j=t_{0}}^{t} \tau_{i j}$, where $\tau_{i j}$ is a $0 / 1$ indicator for positive training expenditures (regardless of the type of training, or in one specific training category, depending on the specification). Thus, our empirical model will identify an increase in the stock of knowledge after the acquisition that the firm would not have produced if it had stayed domestic instead of being acquired by a foreign company.

To establish a causal effect of foreign ownership on the acquired firm's number of high-skilled workers we estimate the following equation:

$$
h_{i t}=\gamma F_{i t-1}+\boldsymbol{\beta} \mathbf{X}_{i t-2}+\eta_{i}+\eta_{s t}+\varepsilon_{i t}
$$

and accordingly for the effect on worker training (where we use $\tau_{i t}$ instead of $h_{i t}$ as the dependent variable). In this equation, $F_{i t-1}$ is a foreign ownership dummy lagged by one period, $\eta_{i}$ is a firm fixed effect, $\eta_{s t}$ is an industry-year fixed effect (to control for general time trends and industry shocks), $\mathbf{X}_{i t-2}$ is a vector of time-varying firm-level controls (lagged by one period relative to the acquisition and with a corresponding vector of parameters $\boldsymbol{\beta}$ to be estimated), and $\varepsilon_{i t}$ is an error term with zero conditional mean. The parameter of interest in this equation is $\gamma$, which captures the effect of a change from domestic to foreign ownership. Identifying $\gamma$ from within-firm variation means that all firm-specific factors are controlled for in the estimation as long as they are constant through time (e.g. the exogenous productivity level $\phi$ in our model, which influences both selection into foreign ownership and skill upgrading). ${ }^{25}$

\footnotetext{
${ }^{23}$ Recent university graduates are defined as recent graduates from a five-year university programme regardless of the field of study.

${ }^{24}$ In the Appendix we employ a direct measure of skill intensity (the share of workers with a five-year university degree) which is available every four years. See also footnote 29.

${ }^{25}$ Our model implies that selection is not random. Instead, foreign MNEs do cherry-picking, i.e., they acquire the most productive domestic firms (those with a high $\phi$ ). This implication is shared by the model presented in Guadalupe et al. (2012) and supported by their empirical analysis of ESEE data for the period 1990-2006. We have replicated their analysis for the period 1998-2013 and found qualitatively identical results; see Table A.2 in the Appendix.
} 
However, controlling for firm fixed effects is not enough to establish causality, because selection into foreign ownership is likely to be driven, not only by time-constant, but also time-varying factors (e.g. the evolution of firm productivity over time). To address this issue and ensure that our parameter estimates reflect skill upgrading associated with a change from domestic to foreign ownership, we closely follow the empirical methodology proposed by Guadalupe et al. (2012). First, we include the vector $\mathbf{X}_{i t-2}$ in the estimation to control for selection on a set of time-varying firm-level characteristics (productivity, productivity growth, average wage, and capital intensity). Second, we augment Eq. (16) by foreign ownership dummies for the current year $\left(F_{i t}\right)$ as well as for the following year $\left(F_{i t+1}\right)$. This allows us to investigate whether firms engage in skill upgrading before the acquisition. And finally, we combine firm fixed effects with a propensity score reweighting estimator to tackle selection into foreign ownership based on past firm characteristics.

Specifically, we construct propensity scores and reweight each observation in (16) in order to generate the same distribution of important observable characteristics across domestically owned and foreign-owned firms. By matching along observable firm characteristics, we hope to also match the distribution of important unobservable characteristics. To estimate the propensity scores, we consider each year in our panel and sort those firms that become foreign owned in that year into the treatment group and those that always remain domestic into the control group. We then pool observations in the treatment and in the control group across all years and obtain the propensity scores for all firms by running industry-specific probit regressions of foreign ownership (the treatment) on productivity, productivity growth, average wage, capital intensity, year dummies, and the firm's hiring and training decisions (all lagged by one year). ${ }^{26}$ As in Guadalupe et al. (2012), we reweight each treated firm by $1 / \hat{p}$ and each control firm by $1 /(1-\hat{p})$, where $\hat{p}$ is the estimated propensity score. ${ }^{27}$

Tables 2 and 3 show the results for our measure of the stock of high-skilled workers $\left(h_{i t}\right)$, and for worker training $\left(\tau_{i t}\right)$. Both tables are organized in the same way with all columns reporting estimates of variants of Eq. (16). Column (1) controls for firm fixed effects $\eta_{i}$; column (2) adds industry-year fixed effects $\eta_{s t}$; column (3) adds the time-varying controls contained in $\mathbf{X}_{i t-2}$; column (4) adds foreign ownership dummies for the current and the following year; and column (5) applies the propensity score weighting estimator as described above. ${ }^{28}$

Overall, our estimation results consistently show that acquisition by a foreign MNE leads to skill upgrading, both through an increase in the number of high-skilled workers and through an increase

\footnotetext{
${ }^{26}$ In addition to our measures of the stock of high-skilled workers $\left(h_{i t-1}\right)$ and the stock of knowledge $\left(\tau_{i t-1}\right)$ we include the firm's 0/1 hiring and training decisions in the pre-treatment year as covariates, respectively. We thus allow the propensity scores to depend, not just on the stock of high-skilled workers and the stock of knowledge, but also on recent hiring and training decisions.

${ }^{27}$ We only keep those observations in the analysis that are in the region of common support, and we have checked that the balancing property is supported by the data in all industries, i.e., all observed characteristics of domestically owned and foreign-owned firms are balanced. Detailed output of the propensity score estimation can be found in Section S.1 of the online supplement to this paper.

${ }^{28}$ Column (4) is always presented with the smallest number of observations due to the leads and lags of the independent variables. In Table S.2 of the online supplement to this paper we present estimates of specifications (1)-(3) using just the observations of the restricted sample in column (4).
} 
Table 2: The effect of foreign ownership on hiring of recent university graduates

\begin{tabular}{|c|c|c|c|c|c|}
\hline & \multicolumn{5}{|c|}{ Hires of recent university graduates } \\
\hline & (1) & $(2)$ & (3) & $(4)$ & $(5)$ \\
\hline \multirow[t]{2}{*}{ Lag foreign } & $1.279^{* * *}$ & $0.599^{* * *}$ & $0.331^{*}$ & 0.230 & $0.416^{* *}$ \\
\hline & $(0.206)$ & $(0.159)$ & $(0.198)$ & $(0.168)$ & $(0.200)$ \\
\hline \multirow[t]{2}{*}{ Foreign } & & & & $0.211^{*}$ & \\
\hline & & & & $(0.123)$ & \\
\hline \multirow[t]{2}{*}{ Forward foreign } & & & & -0.0871 & \\
\hline & & & & $(0.172)$ & \\
\hline Firm fixed effects & Yes & Yes & Yes & Yes & Yes \\
\hline Industry-year fixed effects & & Yes & Yes & Yes & Yes \\
\hline Time-varying controls & & & Yes & Yes & \\
\hline Propensity Score & & & & & Yes \\
\hline Observations & 20049 & 20049 & 13816 & 11517 & 15007 \\
\hline R-squared & 0.010 & 0.366 & 0.364 & 0.374 & 0.427 \\
\hline
\end{tabular}

Notes: The dependent variable in all columns is our measure of the stock of high-skilled workers defined as $h_{i t}=$ $\sum_{j=t_{0}}^{t} h_{i j}$, where $h_{i j}$ is a $0 / 1$ indicator variable for hires of recent university graduates. Foreign is a dummy variable for foreign ownership (equal to one if the firm is foreign owned by more than 50 percent and zero otherwise). Timevarying controls include firm-specific productivity, productivity growth, average wage, and capital intensity (all with a two-year lag). For details on the propensity score reweighting estimator see the text. Robust standard errors (in parentheses) are clustered at the firm level. ${ }^{*},{ }^{* *},{ }^{* * *}$ denote significance at the $10 \%, 5 \%, 1 \%$ levels, respectively.

in worker training. More specifically, columns (1) to (3) in Table 2 show a positive and significant coefficient of lagged foreign ownership (ranging between +0.33 and +1.28 ) suggesting a considerable change in the hiring policy towards recent university graduates after the acquisition. Column (4) shows that, while approximately half of the effect materializes in the acquisition year and another half with a one-year lag (the coefficients of $F_{i t}$ and $F_{i t-1}$ both lie in the vicinity of +0.22 ), there was no effect taking place in the acquired firm before the acquisition (the coefficient of $F_{i t+1}$ is equal to -0.09 and not significantly different from zero). Finally, our propensity score estimates in column (5) also show a positive and significant coefficient of lagged foreign ownership, implying that the effect is unlikely to be driven by endogeneity due to selection into foreign ownership. ${ }^{29}$

As for the effect of foreign ownership on worker training, we find very similar results. In Table 3 we find a positive and significant coefficient of lagged foreign ownership across all specifications employed. The coefficients in columns (1) to (3) vary between +0.55 and +1.7 indicating a sizeable effect. As before in the case of hiring of recent university graduates we see that almost one half of the training effect materializes in the year of acquisition, and the remaining effect with a one-year

\footnotetext{
${ }^{29}$ To substantiate our interpretation that these results indicate a shift in the hiring policy towards high-skilled workers, with an associated increase in the skill intensity of acquired firms, we present two additional results in Appendix A.3.1. First, we show that foreign ownership does not change the hiring policy towards another group of workers, namely those with corporate R\&D experience. Hence, it is not employment across the board in all worker groups that rises due to foreign ownership. Secondly, we show that foreign ownership leads to an increase also in a direct measure of skill intensity, viz. in the share of workers with a five-year university degree. However, since this measure is not available every year in our data, but every four years, we focus on the hiring of recent university graduates in the text.
} 
Table 3: The effect of foreign ownership on worker training

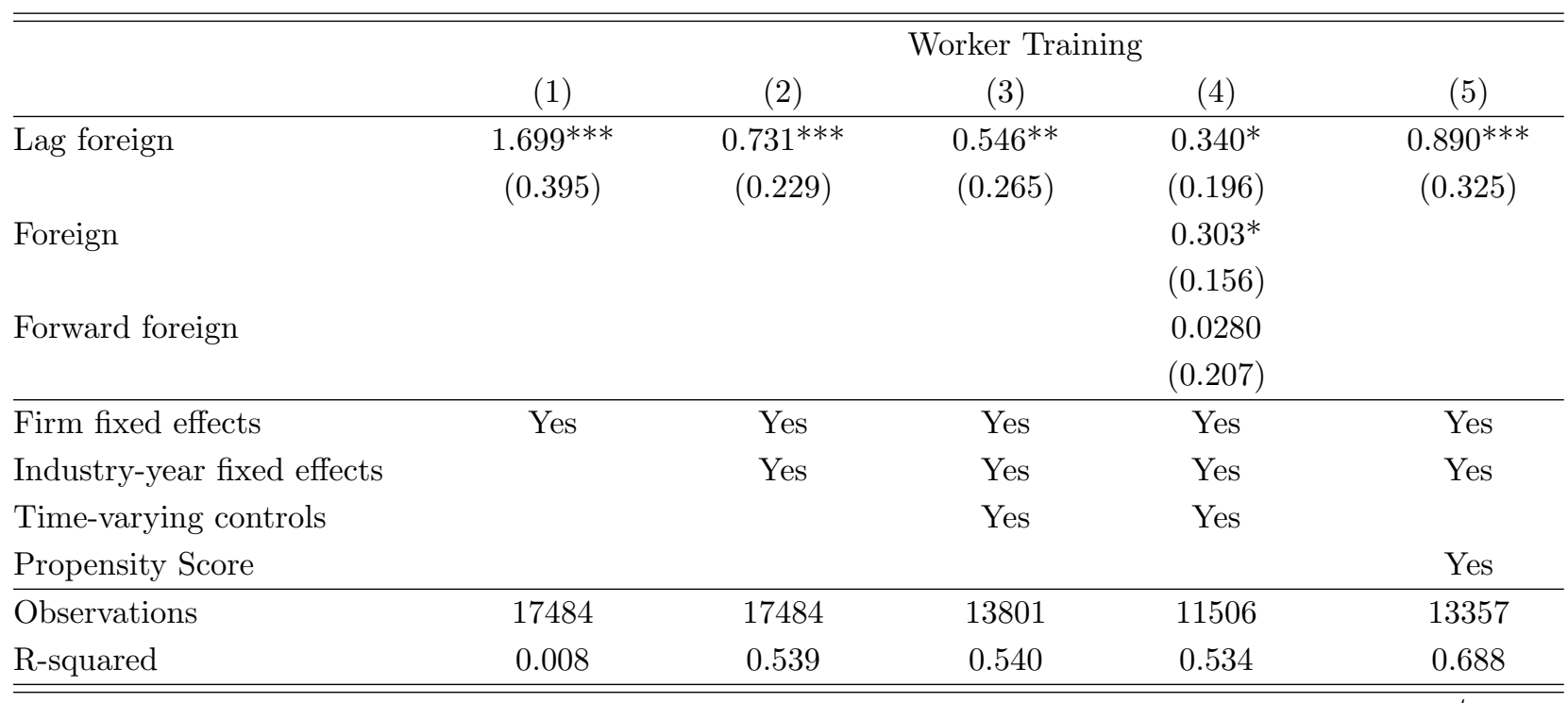

Notes: The dependent variable in all columns is our measure of the stock of knowledge defined as $\tau_{i t}=\sum_{j=t_{0}}^{t} \tau_{i j}$, where $\tau_{i j}$ is a $0 / 1$ indicator variable for positive expenditures on worker training (regardless of the training category). Foreign is a dummy variable for foreign ownership (equal to one if the firm is foreign owned by more than 50 percent and zero otherwise). Time-varying controls include firm-specific productivity, productivity growth, average wage, and capital intensity (all with a two-year lag). For details on the propensity score reweighting estimator see the text. Robust standard errors (in parentheses) are clustered at the firm level. * ,**,*** denote significance at the $10 \%, 5 \%$, $1 \%$ levels, respectively.

lag; see column (4). The propensity score reweighting estimator in column (5) also points towards a highly significant effect of foreign ownership on worker training (with a coefficient of $F_{i t-1}$ equal to +0.89$)$.

Note that in Table 3 we do not distinguish between different types of training. This means that the identified effect of foreign ownership might apply to certain types of training, but not to others. A concern would be that it applies just to those types that are not directly related to the firm's production technology (such as marketing or language). To investigate this possibility, we run the same regressions as in Table 3 separately for the five different types of training. We find in these regressions that the effect of foreign ownership is, in fact, not limited to certain types of training. On the contrary, we find that acquired firms intensify worker training across the board in all forms of training (including engineering and IT). In the interest of space we relegate detailed results to Appendix A.3.2.

\subsection{The market size effect}

We continue our analysis by investigating what is behind the effect of foreign ownership identified in the previous step of our analysis. The focus of our theoretical model is the market size channel, which implies that foreign market access through the foreign parent provides incentives for acquired firms to engage in skill upgrading. In this section we aim to show that it is this channel, rather than foreign ownership per se, which leads to skill upgrading.

We apply two different strategies to pinpoint the market size channel as the driving force be- 
hind the effect of foreign ownership on skill upgrading. The first strategy is to show that foreign ownership interacts with the export status of the acquired firm, in the sense that among the set of acquired firms it is only those firms exporting (or starting to export) that engage in skill upgrading. Those firms serving only the domestic market before and after the acquisition, in contrast, do not exhibit a different behavior than never-acquired firms. The second strategy is to use explicit information available in the ESEE data on how firms access foreign markets (through the foreign parent or through other means), and to show that it is only those firms using their foreign parents to access foreign markets which experience significant skill upgrading. Importantly, we find consistent evidence for the market size effect across both margins of skill upgrading: hiring of high-skilled workers and worker training. ${ }^{30}$

More specifically, in the first four columns in Table 4 we regress our measure of the stock of high-skilled workers, $h_{i t}$, on firm-level dummies for export status and foreign ownership (lagged by one year). As before, we use firm fixed effects, industry-year fixed effects, and a set of time-varying firm-level controls (lagged by two years). Export status alone enters the regression with a positive and significant coefficient indicating that firms starting to export hire more high-skilled workers; see column (1). This effect survives in column (2) where we bring in foreign ownership, which itself enters with a positive and highly significant coefficient equal to +0.61 . More importantly, when we interact the two variables we find that the interaction effect is positive and significant, standing at +0.99 , while the main effects of both export status and foreign ownership enter insignificantly. This finding suggests that it is not the acquisition alone that triggers a change in the firm's hiring policy, but rather improved access to foreign markets facilitated by the foreign parent. In column (4) the coefficient of the interaction term loses its significance, but, as we have verified, this is due to the reduced sample size relative to column (3), not the inclusion of time-varying firm-level characteristics. $^{31}$

In the last two columns in Table 4 we use explicit information on how the firm accesses the export market. This information is available in the ESEE data not every year, but every four years, which is why we lose a considerable number of observations in this analysis. In the estimations we include the standard set of controls, lagged foreign ownership, and a 0/1 indicator variable for whether the firm uses the foreign parent in serving foreign markets. The effect of export status as such cannot be identified in this estimation, as all acquired firms that start exporting do so through their foreign parent. Foreign ownership, in contrast, is not collinear with exporting through the foreign parent, which allows us to include the two variables simultaneously. We find a positive and significant effect of exporting through the foreign parent, both with the standard fixed effects estimator and the propensity score weighting estimator. In contrast, the coefficient of the foreign ownership dummy, while positive, is no longer significant (in a statistical sense).

We find an almost identical pattern in Table 5, which shows the effects on worker training

\footnotetext{
${ }^{30}$ In Appendix A.4.1 we also investigate the possibility that skill upgrading takes places in response to a technology transfer from the foreign owner to the acquired firm. We find no evidence for this alternative channel through which foreign ownership might lead to skill upgrading.

${ }^{31}$ Notice that the interaction effect is identified through both continuous exporters and export switchers.
} 
(i.e., on our measure of the stock of knowledge, $\tau_{i t}$ ). In particular, we find a positive and highly significant interaction effect between export status and foreign ownership (while the main effects of the two variables are insignificant), as well as a positive and significant effect of exporting through the foreign parent (regardless of the estimator used). Hence, foreign ownership triggers worker training, but the market size channel seems to be crucial also for this result. ${ }^{32}$

Table 4: The market size effect on hiring of recent university graduates

\begin{tabular}{|c|c|c|c|c|c|c|}
\hline & \multicolumn{6}{|c|}{ Hires of recent university graduates } \\
\hline & $(1)$ & $(2)$ & $(3)$ & $(4)$ & $(5)$ & $(6)$ \\
\hline \multirow[t]{2}{*}{ Export via foreign parent } & & & & & $0.981^{*}$ & $0.682^{*}$ \\
\hline & & & & & $(0.501)$ & $(0.397)$ \\
\hline \multirow{2}{*}{ Lag foreign } & & $0.608^{* * *}$ & -0.320 & -0.677 & 0.730 & 0.148 \\
\hline & & $(0.158)$ & $(0.472)$ & $(0.672)$ & $(0.514)$ & $(0.355)$ \\
\hline \multirow[t]{2}{*}{ Export } & $0.110^{* *}$ & $0.0932^{*}$ & 0.0872 & 0.00961 & & \\
\hline & $(0.0550)$ & $(0.0562)$ & $(0.0557)$ & $(0.0590)$ & & \\
\hline \multirow[t]{2}{*}{ Export $\times$ Lag foreign } & & & $0.989^{*}$ & 1.090 & & \\
\hline & & & $(0.507)$ & $(0.700)$ & & \\
\hline Firm fixed effects & Yes & Yes & Yes & Yes & Yes & Yes \\
\hline Industry-year fixed effects & Yes & Yes & Yes & Yes & Yes & Yes \\
\hline Time-varying controls & & & & Yes & Yes & \\
\hline Propensity Score & & & & & & Yes \\
\hline Observations & 23449 & 20029 & 20029 & 13802 & 1830 & 2307 \\
\hline R-squared & 0.372 & 0.366 & 0.367 & 0.366 & 0.496 & 0.549 \\
\hline
\end{tabular}

Taken together, our results suggest that the market size effect plays a primary role in the skill upgrading of acquired firms. Our evidence importantly complements the findings in Guadalupe et al. (2012) that acquired firms innovate more upon acquisition (which is likewise driven by the market size channel). While both effects, skill upgrading and innovation, thus seem to be caused by the same underlying factor (viz. access to a larger market through foreign ownership), the two effects might also reinforce each other. Our theoretical model incorporates this possibility by introducing a complementarity between innovation and the skill intensity of the firm, as well as between innovation and worker training. To shed some more light on these complementarities is the purpose of the next step of our analysis.

\footnotetext{
${ }^{32}$ We report regression results for the market size effect on different types of worker training in Appendix A.4.2.
} 
Table 5: The market size effect on worker training

\begin{tabular}{|c|c|c|c|c|c|c|}
\hline & \multicolumn{6}{|c|}{ Worker training } \\
\hline & (1) & $(2)$ & (3) & (4) & $(5)$ & $(6)$ \\
\hline Export via foreign parent & & & & & $\begin{array}{c}0.942^{* *} \\
(0.446)\end{array}$ & $\begin{array}{l}0.636^{*} \\
(0.335)\end{array}$ \\
\hline Lag foreign & & $\begin{array}{c}0.743^{* * *} \\
(0.224)\end{array}$ & $\begin{array}{l}-0.507 \\
(0.424)\end{array}$ & $\begin{array}{l}-0.662 \\
(0.437)\end{array}$ & $\begin{array}{c}0.563 \\
(0.516)\end{array}$ & $\begin{array}{c}0.440 \\
(0.496)\end{array}$ \\
\hline Export & $\begin{array}{c}0.115 \\
(0.0739)\end{array}$ & $\begin{array}{c}0.100 \\
(0.0804)\end{array}$ & $\begin{array}{c}0.0904 \\
(0.0801)\end{array}$ & $\begin{array}{c}0.0195 \\
(0.0963)\end{array}$ & & \\
\hline Export $\times$ Lag foreign & & & $\begin{array}{c}1.334^{* * *} \\
(0.452)\end{array}$ & $\begin{array}{c}1.305^{* * *} \\
(0.477)\end{array}$ & & \\
\hline$\overline{\text { Firm fixed effects }}$ & Yes & Yes & Yes & Yes & Yes & Yes \\
\hline Industry-year fixed effects & Yes & Yes & Yes & Yes & Yes & Yes \\
\hline Time-varying controls & & & & Yes & Yes & \\
\hline Propensity Score & & & & & & Yes \\
\hline Observations & 19249 & 17467 & 17467 & 13787 & 1822 & 2298 \\
\hline R-squared & 0.539 & 0.539 & 0.540 & 0.541 & 0.641 & 0.704 \\
\hline
\end{tabular}

Notes: The dependent variable in all columns is our measure of the stock of knowledge defined as $\tau_{i t}=\sum_{j=t_{0}}^{t} \tau_{i j}$, where $\tau_{i j}$ is a $0 / 1$ indicator variable for positive expenditures on worker training (regardless of the training category). Foreign is a dummy variable for foreign ownership (equal to one if the firm is foreign owned by more than 50 percent and zero otherwise). Export via foreign parent is a dummy variable indicating whether the firm uses the foreign parent as a distribution channel to access foreign markets. Export is a dummy variable for positive exports. Timevarying controls include firm-specific productivity, productivity growth, average wage, and capital intensity (all with a two-year lag). For details on the propensity score reweighting estimator see the text. Robust standard errors (in parentheses) are clustered at the firm level. $* * *, * * *$ denote significance at the $10 \%, 5 \%, 1 \%$ levels, respectively.

\subsection{The productivity effects of both skill and technology upgrading}

We now look into the productivity effects associated with both skill and technology upgrading. This part of our analysis is motivated by the technology-skill complementarity postulated in our theoretical model. The results we present in the following are consistent with the hypothesis of skillbiased technological change induced by foreign ownership, i.e., shifts in the technological frontier that favor the relative productivity of skilled over unskilled labor.

In particular, our model suggests that while innovation raises the firm's productivity, the full productivity gains will only materialize if the firm engages in both innovation and skill upgrading simultaneously. Guadalupe et al. (2012) have shown that acquired firms, first, innovate more upon acquisition (due to the market size effect), and second, experience a subsequent productivity gain relative to non-acquired firms. ${ }^{33}$ In the following regression analysis we wish to show that this productivity gain derives from a crucial interaction between innovation and skill upgrading.

The ESEE data provide a wide variety of information on specific innovation activities of the firm. Our focus is on two fundamentally different types of innovation-process innovation and product

\footnotetext{
${ }^{33}$ We have verified that these results hold also in our sample period (1998-2013). For details see Section S.3 of the online supplement.
} 
Table 6: The productivity effects of skill upgrading and process innovation

\begin{tabular}{|c|c|c|c|c|c|c|c|}
\hline & \multicolumn{7}{|c|}{ TFP (in logs) } \\
\hline & $(1)$ & $(2)$ & $(3)$ & (4) & $(5)$ & $(6)$ & $(7)$ \\
\hline \multirow[t]{2}{*}{ Process innovation (stock; in logs) } & $0.199^{* * *}$ & $0.199^{* * *}$ & $0.180^{* * *}$ & $0.116^{* * *}$ & $0.212^{* * *}$ & $0.175^{* * *}$ & $0.203^{* * *}$ \\
\hline & $(0.0173)$ & $(0.0173)$ & $(0.0175)$ & $(0.0297)$ & $(0.0201)$ & $(0.0212)$ & $(0.0555)$ \\
\hline \multirow[t]{2}{*}{ Hiring (current) } & & $0.0406^{* * *}$ & $-0.0310^{*}$ & $-0.209 * *$ & & & \\
\hline & & $(0.0119)$ & $(0.0176)$ & $(0.0995)$ & & & \\
\hline \multirow[t]{2}{*}{ Hiring $\times$ Process innovation } & & & $0.0722^{* * *}$ & $0.220 * * *$ & & & \\
\hline & & & $(0.0156)$ & $(0.0779)$ & & & \\
\hline \multirow[t]{2}{*}{ Training (current) } & & & & & $0.0570^{* * *}$ & -0.00631 & 0.0255 \\
\hline & & & & & $(0.0106)$ & $(0.0157)$ & $(0.0460)$ \\
\hline \multirow{2}{*}{ Training $\times$ Process innovation } & & & & & & $0.0688^{* * *}$ & $0.110^{* *}$ \\
\hline & & & & & & $(0.0138)$ & $(0.0457)$ \\
\hline Firm fixed effects & Yes & Yes & Yes & Yes & Yes & Yes & Yes \\
\hline Industry-year fixed effects & Yes & Yes & Yes & Yes & Yes & Yes & Yes \\
\hline Propensity Score & & & & Yes & & & Yes \\
\hline Observations & 22697 & 22697 & 22697 & 12487 & 18687 & 18687 & 9469 \\
\hline R-squared & 0.264 & 0.265 & 0.267 & 0.328 & 0.303 & 0.305 & 0.371 \\
\hline
\end{tabular}

Notes: The dependent variable in all columns is the firm-specific total factor productivity (in logs) estimated with the Olley and Pakes (1996) estimation routine. Process innovation (in logs) is a measure of the technology level of the firm given by $\rho_{i t}=\sum_{j=t_{0}}^{t} \rho_{i j}$, where $\rho_{i j}$ is a $0 / 1$ indicator for process innovation. Hiring and training are dummy variables for hiring of recent university graduates and positive expenditures on worker training, respectively. For details on the propensity score reweighting estimator see the text. Robust standard errors (in parentheses) are clustered at the firm level. $*, * *, * * *$ denote significance at the $10 \%, 5 \%, 1 \%$ levels, respectively.

innovation. ${ }^{34}$ We follow Guadalupe et al. (2012) in assuming that the firm's level of technology at any point in time $t$ is the result of the sum of all innovations that have taken place up to that point: $\rho_{i t}=\sum_{j=t_{0}}^{t} \rho_{i j}$, where $\rho_{i j}$ is a $0 / 1$ indicator for either process or product innovation. We now use these technology variables in a simple regression framework to see whether innovation interacts with skill upgrading in boosting productivity.

We first focus on the effects of process innovation and skill upgrading on productivity; see Table 6. We start by regressing a firm's total factor productivity on the firm's technology level (in logs) using firm fixed effects and industry-year fixed effects. ${ }^{35}$ While industry-year fixed effects control for industry-specific shocks to productivity, the use of within-firm variation in this estimation means that the level of technology when the firm enters the sample in $t_{0}$ is controlled for, and that we relate changes in productivity to changes in technology within a firm over time. We find, in line with Guadalupe et al. (2012), that technology upgrading in the form of process innovation acts as a highly significant productivity shifter; see column (1).

\footnotetext{
${ }^{34}$ Process innovation may refer to the introduction of new machines or the implementation of new methods of organizing production, or both.

${ }^{35}$ We add one to the technology level $\rho_{i t}$ before taking the log to keep observations with zero innovation in the regressions. However, the results do not change in any significant way when we exclude these observations from the estimation.
} 
Table 7: The productivity effects of skill upgrading and product innovation

\begin{tabular}{|c|c|c|c|c|c|c|c|}
\hline & \multicolumn{7}{|c|}{ TFP (in logs) } \\
\hline & $(1)$ & $(2)$ & $(3)$ & $(4)$ & $(5)$ & $(6)$ & $(7)$ \\
\hline Product innovation (stock; in logs) & $\begin{array}{c}0.106^{* * *} \\
(0.0199)\end{array}$ & $\begin{array}{c}0.106^{* * *} \\
(0.0199)\end{array}$ & $\begin{array}{c}0.0865^{* * *} \\
(0.0209)\end{array}$ & $\begin{array}{c}0.0552 \\
(0.0374)\end{array}$ & $\begin{array}{c}0.123^{* * *} \\
(0.0230)\end{array}$ & $\begin{array}{c}0.0946^{* * *} \\
(0.0256)\end{array}$ & $\begin{array}{l}0.252^{*} \\
(0.146)\end{array}$ \\
\hline Hiring (current) & & $\begin{array}{c}0.0404^{* * *} \\
(0.0123)\end{array}$ & $\begin{array}{c}-0.0106 \\
(0.0159)\end{array}$ & $\begin{array}{l}-0.0216 \\
(0.0627)\end{array}$ & & & \\
\hline Hiring $\times$ Product innovation & & & $\begin{array}{c}0.0665^{* * *} \\
(0.0162)\end{array}$ & $\begin{array}{c}0.127^{* *} \\
(0.0633)\end{array}$ & & & \\
\hline Training (current) & & & & & $\begin{array}{c}0.0586^{* * *} \\
(0.0108)\end{array}$ & $\begin{array}{c}0.0325^{* *} \\
(0.0138)\end{array}$ & $\begin{array}{c}0.112^{* * *} \\
(0.0364)\end{array}$ \\
\hline Training $\times$ Product innovation & & & & & & $\begin{array}{c}0.0450^{* * *} \\
(0.0146)\end{array}$ & $\begin{array}{c}0.0511 \\
(0.0371)\end{array}$ \\
\hline Firm fixed effects & Yes & Yes & Yes & Yes & Yes & Yes & Yes \\
\hline Industry-year fixed effects & Yes & Yes & Yes & Yes & Yes & Yes & Yes \\
\hline Propensity Score & & & & Yes & & & Yes \\
\hline Observations & 22697 & 22697 & 22697 & 12487 & 18687 & 18687 & 9469 \\
\hline R-squared & 0.250 & 0.251 & 0.253 & 0.317 & 0.291 & 0.292 & 0.364 \\
\hline
\end{tabular}

Notes: The dependent variable in all columns is the firm-specific total factor productivity (in logs) estimated with the Olley and Pakes (1996) estimation routine. Product innovation (in logs) is a measure of the technology level of the firm given by $\rho_{i t}=\sum_{j=t_{0}}^{t} \rho_{i j}$, where $\rho_{i j}$ is a $0 / 1$ indicator for product innovation. Hiring and training are dummy variables for hiring of recent university graduates and positive expenditures on worker training, respectively. For details on the propensity score reweighting estimator see the text. Robust standard errors (in parentheses) are clustered at the firm level. $*, * *, * * *$ denote significance at the $10 \%, 5 \%, 1 \%$ levels, respectively.

In columns (2) and (5) we augment the model to include a dummy variable for whether the firm hired recent university graduates and for whether the firm had positive expenditures on worker training, respectively. ${ }^{36}$ We find evidence that both hiring and worker training (the two activities triggered by a change from domestic to foreign ownership) increase productivity, since both variables enter the regression with a positive and highly significant coefficient. In columns (3) and (6) we interact the two variables with process innovation. These regressions reveal that the productivity gains are largest in firms with a high technology level. This is evidenced by the highly significant and positive coefficients of the respective interaction terms. In columns (4) and (7) we combine firm fixed effects with a propensity score reweighting estimator to control for selection into hiring and training based on past firm characteristics. ${ }^{37}$ We find strong interaction effects also with this

\footnotetext{
${ }^{36}$ We include dummy variables for hiring and training rather than the stock of high-skilled workers and the stock of knowledge, respectively, since this allows us to control for endogenous selection into hiring and training through propensity score estimation; see below. However, as part of our robustness checks, we also use the stock variables rather than the $0 / 1$ indicators, to find qualitatively similar results as in the regressions reported here; see Section S.4 in the online supplement to our paper.

${ }^{37}$ Specifically, to estimate the propensity scores for the estimation in column (4), we only keep those observations that report no hiring (control group) as well as those observations that start hiring in the current period, continue hiring afterwards, and never hired before (treatment group). We then pool observations in the treatment and in the control group across all years and obtain the propensity scores for all firms by running industry-specific probit regressions of hiring (the treatment) on lagged productivity, lagged productivity growth, lagged average wage, lagged capital intensity, and year fixed effects. We proceed accordingly for the estimation in column (7) using training instead
} 
alternative estimator.

We next estimate the effects of product innovation and skill upgrading on productivity; see Table 7. The table is organized in the same way as the previous table, and the results are strikingly similar. The results in column (1) indicate that technology upgrading in the form of product innovation raises the firm's productivity level. However, the effects are considerably larger when technology upgrading is accompanied by an increase in the number of high-skilled workers (hiring) as well as an increase in worker training. This can be seen from the positive and significant interaction effects between product innovation and hiring and training in Table 7 .

\section{Conclusion}

In this paper we develop a model of foreign ownership and skill-biased technological change in which heterogeneous firms decide endogenously about the level of technology, the share of highskilled workers in production, and the level of worker training. A crucial feature of our model is a technology-skill complementarity which implies that adopting new and superior technology creates incentives for firms to enhance workforce skills (through both hiring of high-skilled workers and worker training). The model can be used to study the effects of foreign acquisitions on technology and skill choices within firms, and to identify the sources of productivity gains at the micro level. We test the implications of our model on a longitudinal firm-level data set from Spain and find evidence strongly supportive of the model.

By focusing attention on endogenous skill adjustments within foreign-acquired firms, we believe that our paper speaks to the public debate about the costs and benefits of multinational firm activity and foreign acquisitions. There seems to be a widespread concern that foreign acquisitions may harm domestic workers through job losses and wage cuts, and these concerns seem to be most pronounced in the case of low-skilled rather than high-skilled workers. While our paper does not lend itself to an analysis of the distributional effects of foreign acquisitions or their welfare consequences, it nevertheless paints a nuanced picture of the within-firm skill changes caused by foreign acquisitions. On the one hand, we find an increase in the relative demand for high-skilled labor. This finding refers to the classical distinction between high- and low-skilled labor based on the formal education of workers. On the other hand, we also find a significant increase in worker training. This dimension has often been neglected in the debate about the implications of skillbiased technological change, although worker training provides a direct and positive stimulus for the stock of human capital available in a country, with important implications for future innovation and growth.

\section{References}

Acemoglu, Daron. (1997). 'Training and innovation in an imperfect labour market', Review of of hiring. 
Economic Studies 64(3), 445-464.

Acemoglu, Daron. (2003). 'Patterns of skill premia', Review of Economic Studies 70(2), 199-230.

Acemoglu, Daron and Autor, David H. (2011), Chapter 12 - Skills, tasks and technologies: Implications for employment and earnings, in Orley Ashenfelter and David Card., eds, 'Handbooks in Economics Handbook of Labor Economics', Vol. 4, Part B, Elsevier, pp. 10431171.

Aitken, Brian J. and Harrison, Ann E. (1999). 'Do domestic firms benefit from direct foreign investment? Evidence from Venezuela', American Economic Review 89(3), 605-618.

Akerman, Anders, Gaarder, Ingvil and Mogstad, Magne. (2015). 'The skill complementarity of broadband internet', Quarterly Journal of Economics 130(4), 1781-1824.

Almeida, Rita. (2007). 'The labor market effects of foreign owned firms', Journal of International Economics 72(1), 75-96.

Antràs, Pol. (2015), Global production: Firms, contracts, and trade structure, Princeton University Press.

Arnold, Jens M. and Javorcik, Beata S. (2009). 'Gifted kids or pushy parents? Foreign direct investment and plant productivity in Indonesia', Journal of International Economics 79(1), 42-53.

Autor, David H., Levy, Frank and Murnane, Richard J. (2003). 'The skill content of recent technological change: An empirical exploration', Quarterly Journal of Economics 118(4), 12791333.

Blonigen, Bruce A. and Slaughter, Matthew J. (2001). 'Foreign-affiliate activity and US skill upgrading', Review of Economics and Statistics 83(2), 362-376.

Bloom, Nicholas and Van Reenen, John. (2010). 'Why do management practices differ across firms and countries?', Journal of Economic Perspectives 24(1), 203-224.

Bøler, Esther A. (2015). 'Technology-skill complementarity in a globalized world'. University of Oslo, mimeo.

Bond, Stephen and Van Reenen, John. (2007). 'Microeconometric models of investment and employment', Handbook of Econometrics 6, 4417-4498.

Caves, Richard E. (1996), Multinational enterprise and economic analysis, Cambridge university press.

Criscuolo, Chiara and Martin, Ralf. (2009). 'Multinationals and US productivity leadership: Evidence from Great Britain', Review of Economics and Statistics 91(2), 263-281. 
Delgado, Miguel A., Fariñas, Jose C. and Ruano, Sonia. (2002). 'Firm productivity and export markets: A non-parametric approach', Journal of International Economics 57(2), 397-422.

De Loecker, Jan. (2007). 'Do exports generate higher productivity? Evidence from Slovenia', Journal of International Economics 73(1), 69-98.

Fabbri, Francesca, Haskel, Jonathan E. and Slaughter, Matthew J. (2003). 'Does nationality of ownership matter for labor demands?', Journal of the European Economic Association $1(2-3), 698-707$.

Garicano, Luis and Steinwender, Claudia. (2016). 'Survive another day: Using changes in the composition of investments to measure the cost of credit constraints', Review of Economics and Statistics 98(5), 913-924.

Girma, Sourafel, Gong, Yundan, Görg, Holger and Lancheros, Sandra. (2015). 'Estimating direct and indirect effects of foreign direct investment on firm productivity in the presence of interactions between firms', Journal of International Economics 95(1), 157-169.

Goldin, Claudia and Katz, Lawrence F. (2007). 'Long-run changes in the wage structure: Narrowing, widening, polarizing', Brookings Papers on Economic Activity 38(2), 135-168.

Guadalupe, Maria, Kuzmina, Olga and Thomas, Catherine. (2012). 'Innovation and foreign ownership', American Economic Review 102(7), 3594-3627.

Heyman, Fredrik, Sjöholm, Fredrik and Tingvall, Patrik G. (2007). 'Is there really a foreign ownership wage premium? Evidence from matched employer-employee data', Journal of International Economics 73(2), 355-376.

Hijzen, Alexander, Martins, Pedro S., Schank, Thorsten and Upward, Richard. (2013). 'Foreign-owned firms around the world: A comparative analysis of wages and employment at the micro-level', European Economic Review 60, 170-188.

Huttunen, Kristiina. (2007). 'The Effect of foreign acquisition on employment and wages: Evidence from Finnish establishments', Review of Economics and Statistics 89(3), 497-509.

Ichniowski, Casey, Bartel, Ann and Shaw, Kathryn. (2007). 'How does information technology really affect productivity? Plant-level comparisons of product innovation, process improvement and worker skills', Quarterly Journal of Economics 122(4), 1721-1758.

Javorcik, Beata S. (2004). 'Does foreign direct investment increase the productivity of domestic firms? In search of spillovers through backward linkages', American Economic Review 94(3), 605627.

Koch, Michael. (2016). 'Skills, tasks and the scarcity of talent in a global economy', Review of International Economics 24(3), 536-563. 
Kohler, Wilhelm and Smolka, Marcel. (2014). 'Global sourcing and firm selection', Economics Letters 124(3), 411-415.

Levy, Frank and Murnane, Richard J. (1996). 'With what skills are computers a complement?', American Economic Review 86(2), 258-262.

Lewis, Ethan. (2011). 'Immigration, skill mix, and capital skill complementarity', Quarterly Journal of Economics 126(2), 1029-1069.

Olley, G. Steven and Pakes, Ariel. (1996). 'The dynamics of productivity in the telecommunications equipment industry', Econometrica 64(6), 1263-1297.

Ramondo, Natalia. (2009). 'Foreign plants and industry productivity: Evidence from Chile', Scandinavian Journal of Economics 111(4), 789-809.

Sabirianova, Klara, Svejnar, Jan and Terrell, Katherine. (2005). 'Distance to the efficiency frontier and foreign direct investment spillovers', Journal of the European Economic Association $3(2-3), 576-586$.

Stiebale, Joel. (2016). 'Cross-border M\&As and innovative activity of acquiring and target firms', Journal of International Economics 99, 1-15.

Syverson, Chad. (2011). 'What determines productivity?', Journal of Economic Literature $49(2), 326-65$.

Taylor, Karl and Driffield, Nigel. (2005). 'Wage inequality and the role of multinationals: Evidence from UK panel data', Labour Economics 12(2), 223-249.

Yasar, Mahmut and Morrison Paul, Catherine J. (2007). 'International linkages and productivity at the plant level: Foreign direct investment, exports, imports and licensing', Journal of International Economics 71(2), 373-388. 


\section{A Appendix}

\section{A.1 Further descriptive statistics}

Table A.1: Further descriptive statistics

\begin{tabular}{lccc}
\hline \hline & Domestic & Foreign & Observations \\
\hline Labor productivity growth & -0.007 & 0.005 & 19,720 \\
& $(0.529)$ & $(0.523)$ & \\
Hires of workers with corporate R\&D experience & 0.039 & 0.044 & 23,474 \\
& $(0.194)$ & $(0.206)$ & \\
Share of high-skilled workers & 0.049 & 0.085 & 7,544 \\
Average wage (in logs) & $(0.075)$ & $(0.074)$ & 23,303 \\
Capital intensity (in logs) & 15.761 & 23.738 & 22,794 \\
& $(6.427)$ & $(7.205)$ & \\
Export via foreign parent & 3.191 & 3.967 & 4,297 \\
Export & $(1.177)$ & $(0.863)$ & 23,449 \\
& 0.001 & 0.415 & \\
\hline
\end{tabular}

Notes: This table shows means and standard deviations (in parentheses) for additional variables that are used throughout the empirical analysis. Variables are grouped by ownership status of the firm (domestically owned versus foreign owned). The number of observations reported in the final column sums across both domestically owned and foreign-owned firms. The sample spans the years 1998-2013 and is restricted to firms that are owned domestically in the first year they enter the sample. Labor productivity growth is the annual growth rate of real value added per effective working hour. Hires of workers with corporate R\&D experience is a dummy variable indicating whether the firm hired the respective workers in a given year. High-skilled workers are defined as workers with a five-year university degree. Average wage is the natural logarithm of the real total wage bill per worker. Capital intensity is the log capital per employee. Export via foreign parent is a dummy variable indicating whether the firm uses the foreign parent as a distribution channel to access foreign markets. Export is a dummy variable for positive exports.

Source: Authors' computations based on ESEE data.

\section{A.2 Cherry picking by foreign investors}

In Table A.2 we test whether foreign firms acquire the most productive firms in Spain in our sample period from 1998-2013. This analysis replicates Table 2 on p. 3608 in Guadalupe et al. (2012) who use an earlier sample period (1990-2006). Besides small deviations in the point estimates the significance of the coefficients remains unaffected by the change in the sample period, which provides evidence for "cherry picking" by foreign investors.

More specifically, Panel A reports estimates of an equation of the following form:

$$
F_{i}=\alpha+\beta \phi_{i 0}+d_{s}+\epsilon_{i}
$$

where $F_{i}$ is a $0 / 1$ indicator variable for whether firm $i$ was acquired by a foreign company during the sample period (meaning a change in the foreign ownership share to more than 50 percent), $\phi_{i 0}$ is the firm's productivity level in the year of sample entry, $\alpha$ and $\beta$ are parameters to be estimated, $d_{s}$ is an industry fixed effect, and $\epsilon_{i}$ is the error term. Productivity in these regressions is measured 
by the $\log$ of sales (columns 1 to 3 ) or the log of labor productivity (columns 4 to 6 ).

Panel B reports estimates of an equation of the following form:

$$
F_{i t}=\alpha+\beta \phi_{i t-1}+d_{s t}+\epsilon_{i t}
$$

where the dependent variable now refers to the foreign ownership status of firm $i$ in year $t$ (equal to one if the firm is foreign owned by more than 50 percent and zero otherwise), $\phi_{i t-1}$ is lagged productivity, and $d_{s t}$ is an industry-year fixed effect. 
Table A.2: The selection decision: linear probability specification

\begin{tabular}{|c|c|c|c|c|c|c|}
\hline \multirow[b]{2}{*}{ Productivity measure } & \multicolumn{3}{|c|}{ ln sales } & \multicolumn{3}{|c|}{ ln labor productivity } \\
\hline & (1a) & $(2 \mathrm{a})$ & $(3 \mathrm{a})$ & $(4 a)$ & $(5 a)$ & $(6 a)$ \\
\hline \multicolumn{7}{|c|}{ Panel $A$. The probability of being acquired during the sample period } \\
\hline Base year productivity & $\begin{array}{c}0.0208^{* * *} \\
(0.00249)\end{array}$ & & $\begin{array}{c}0.0154^{* * *} \\
(0.00367)\end{array}$ & $\begin{array}{c}0.0188^{* * *} \\
(0.00522)\end{array}$ & & $\begin{array}{c}0.0189^{* * *} \\
(0.00591)\end{array}$ \\
\hline $\begin{array}{l}\text { 2nd quartile base year } \\
\text { productivity }\end{array}$ & & $\begin{array}{c}0.0153^{* * *} \\
(0.00482)\end{array}$ & & & $\begin{array}{c}0.00707 \\
(0.00643)\end{array}$ & \\
\hline 3rd quartile base year & & $0.0332^{* * *}$ & & & $0.0227^{* * *}$ & \\
\hline productivity & & $(0.00659)$ & & & $(0.00753)$ & \\
\hline 4th quartile base year & & $0.0817^{* * *}$ & & & $0.0341^{* * *}$ & \\
\hline productivity & & $(0.00991)$ & & & $(0.00837)$ & \\
\hline Exporting firm in base year & & & $\begin{array}{c}0.00567 \\
(0.00815)\end{array}$ & & & $\begin{array}{c}0.0259^{* * *} \\
(0.00629)\end{array}$ \\
\hline $\begin{array}{l}\text { Exporting in base year } \times \\
\text { base year productivity }\end{array}$ & & & $\begin{array}{l}0.00862^{*} \\
(0.00481)\end{array}$ & & & $\begin{array}{l}-0.00937 \\
(0.00984)\end{array}$ \\
\hline Observations & 3349 & 3349 & 3349 & 3304 & 3304 & 3304 \\
\hline \multirow[t]{2}{*}{$R^{2}$} & 0.051 & 0.045 & 0.052 & 0.019 & 0.021 & 0.026 \\
\hline & $(1 b)$ & $(2 \mathrm{~b})$ & $(3 \mathrm{~b})$ & $(4 b)$ & $(5 \mathrm{~b})$ & $(6 \mathrm{~b})$ \\
\hline \multicolumn{7}{|c|}{ Panel B. The probability of being acquired in a given year } \\
\hline Lagged productivity & $\begin{array}{l}0.00394^{* * *} \\
(0.000511)\end{array}$ & & $\begin{array}{c}0.00355^{* * *} \\
(0.000883)\end{array}$ & $\begin{array}{c}0.00461^{* * *} \\
(0.00122)\end{array}$ & & $\begin{array}{c}0.00403^{* * *} \\
(0.00141)\end{array}$ \\
\hline $\begin{array}{l}\text { 2nd quartile lagged } \\
\text { productivity }\end{array}$ & & $\begin{array}{r}0.00314^{* * *} \\
(0.000872)\end{array}$ & & & $\begin{array}{l}0.000810 \\
(0.00106)\end{array}$ & \\
\hline $\begin{array}{l}\text { 3rd quartile lagged } \\
\text { productivity }\end{array}$ & & $\begin{array}{c}0.00784^{* * *} \\
(0.00155)\end{array}$ & & & $\begin{array}{c}0.00607^{* * *} \\
(0.00149)\end{array}$ & \\
\hline 4th quartile lagged & & $0.0170^{* * *}$ & & & $0.00864^{* * *}$ & \\
\hline productivity & & $(0.00225)$ & & & $(0.00195)$ & \\
\hline Lag exporting firm & & & $\begin{array}{c}-0.000559 \\
(0.00192)\end{array}$ & & & $\begin{array}{c}0.00434^{* * *} \\
(0.00132)\end{array}$ \\
\hline Lag exporting firm $\times$ & & & 0.000702 & & & -0.000833 \\
\hline lagged productivity & & & $(0.00103)$ & & & $(0.00217)$ \\
\hline Observations & 19685 & 19685 & 19668 & 19538 & 19538 & 19522 \\
\hline$R^{2}$ & 0.014 & 0.013 & 0.014 & 0.008 & 0.009 & 0.009 \\
\hline $\begin{array}{l}\text { Industry FEs (both panels) } \\
\text { and year FEs and industry } \\
\text { trends (in panel B) }\end{array}$ & Yes & Yes & Yes & Yes & Yes & Yes \\
\hline
\end{tabular}

Notes: Foreign is a dummy variable for foreign ownership (equal to one if the firm is foreign owned by more than 50 percent and zero otherwise). Base year (lagged) ln sales is the natural logarithm of firm's real sales, relative to the industry mean, in the first year the firm appears in the sample (one year prior to the dependent variable). Base year (lagged) labor productivity is the natural logarithm of real value added per worker, relative to the industry mean, in the first year the firm appears in the sample (one year prior to the dependent variable). Exporting firm in base year equals one if the firm was an exporter in the first year it appears in the sample. Lag exporting firm equals one if the firm was an exporter the previous year. The first year the firm appears in the sample is dropped from all regressions. Panel B regressions condition on the firm being not foreign owned in the previous year. Standard errors are clustered by firm. *,*,*** denote significance at the $10 \%, 5 \%, 1 \%$ levels, respectively. 


\section{A.3 Further results on the effect of foreign ownership on skill upgrading}

\section{A.3.1 Hiring and changes in skill intensity}

In Table 2 we identify the effect of foreign ownership on the firm's hiring of fresh university graduates. We interpret the evidence that we find as indicating a shift in the hiring policy towards high-skilled workers, and thus as an increase in the skill intensity of the firm (corresponding to a decrease in the threshold value $z$ in our theoretical model). To substantiate this interpretation we now present two additional results obtained from our analysis of the ESEE data. First, to see whether foreign ownership changes the hiring policy, not only towards fresh university graduates, but also towards other groups of workers, we use information available in the ESEE data on whether the firm hires workers with corporate $R \& D$ experience. We run the same regressions as in Table 2 , but now the dependent variable is based on hires of workers with corporate $R \& D$ experience rather than hires of recent university graduates. The regression results in Table A.3 indicate no effect of foreign ownership on this aspect of the firm's hiring strategy. This is consistent with our interpretation that the change in the hiring strategy of acquired firms is driven by the desire to increase the skill intensity of the firm, and not by targeting other dimensions of worker heterogeneity.

Table A.3: The effect of foreign ownership on hiring of workers with corporate R\&D experience

\begin{tabular}{|c|c|c|c|c|c|}
\hline & \multicolumn{5}{|c|}{ Hires of workers with corporate R\&D experience } \\
\hline & $(1)$ & $(2)$ & $(3)$ & $(4)$ & $(5)$ \\
\hline \multirow{2}{*}{ Lag foreign } & $0.112^{* *}$ & -0.0525 & -0.0862 & -0.0797 & $-0.144^{* *}$ \\
\hline & $(0.0504)$ & $(0.0527)$ & $(0.0528)$ & $(0.0513)$ & $(0.0703)$ \\
\hline \multirow[t]{2}{*}{ Foreign } & & & & -0.0498 & \\
\hline & & & & $(0.0439)$ & \\
\hline \multirow[t]{2}{*}{ Forward foreign } & & & & -0.0270 & \\
\hline & & & & $(0.0514)$ & \\
\hline Firm fixed effects & Yes & Yes & Yes & Yes & Yes \\
\hline Industry-year fixed effects & & Yes & Yes & Yes & Yes \\
\hline Time-varying controls & & & Yes & Yes & \\
\hline Propensity Score & & & & & Yes \\
\hline Observations & 20049 & 20049 & 13816 & 11517 & 15007 \\
\hline R-squared & 0.000 & 0.137 & 0.144 & 0.147 & 0.119 \\
\hline
\end{tabular}

Notes: The dependent variable in all columns is a measure of the stock of workers with corporate R\&D experience defined as $h_{i t}=\sum_{j=t_{0}}^{t} h_{i j}$, where $h_{i j}$ is a $0 / 1$ indicator variable for hires of workers with corporate R\&D experience. Foreign is a dummy variable for foreign ownership (equal to one if the firm is foreign owned by more than 50 percent and zero otherwise). Time-varying controls include firm-specific productivity, productivity growth, average wage, and capital intensity (all with a two-year lag). For details on the propensity score reweighting estimator see the text. Robust standard errors (in parentheses) are clustered at the firm level. $*, * *, * * *$ denote significance at the $10 \%, 5 \%$, $1 \%$ levels, respectively.

The second additional result derives from using a direct measure of skill intensity rather than variables on hiring. More specifically, we use the log share of high-skilled workers (defined as workers with a five-year university degree) as the dependent variable in regressions that are otherwise 
identical to the ones in Table A.3. This variable has the advantage that it is a direct measure of (the inverse of) the threshold value $z$ in our theoretical model, but unfortunately the ESEE data include this information not every year, but every four years (with 1998 being the first year we observe the variable in our sample). Since we use lagged foreign ownership in the regressions, this implies that we have at most three observations per firm in the data $(2002,2006,2010)$, while we have on average considerably less than two observations per firm in our sample. An additional problem is that the information suffers from heaping, i.e., some firms round the share of high-skilled workers introducing measurement error in the data. The regression results reported in Table A.4 nevertheless indicate a tendency among acquired firms to increase the share of high-skilled workers. We find a positive coefficient of lagged foreign ownership in all specifications, and the coefficient is significantly different from zero in the three most stringent specifications.

Table A.4: The effect of foreign ownership on the share of high-skilled workers

\begin{tabular}{lccccc}
\hline \hline & \multicolumn{4}{c}{ Share of high-skilled workers } \\
& $(1)$ & $(2)$ & $(3)$ & $(4)$ & $(5)$ \\
\hline Lag foreign & 0.245 & 0.0453 & $0.750^{*}$ & $0.886^{* *}$ & $1.456^{* *}$ \\
& $(0.162)$ & $(0.297)$ & $(0.413)$ & $(0.427)$ & $(0.651)$ \\
Foreign & & & -0.0196 & \\
& & & & $(0.455)$ & \\
Forward foreign & & & -0.525 & \\
& & & & $(0.426)$ & \\
\hline Firm fixed effects & Yes & Yes & Yes & Yes & Yes \\
Industry-year fixed effects & & Yes & Yes & Yes & Yes \\
Time-varying controls & & & Yes & Yes & Yes \\
Propensity Score & & & & 1839 & 1653 \\
Observations & 2795 & 2795 & 2049 & 0.121 & 0.136 \\
R-squared & 0.000 & 0.062 & 0.113 & & \\
\hline \hline
\end{tabular}

Notes: The dependent variable in all columns is the log share of high-skilled workers (defined as workers with a fiveyear university degree). Foreign is a dummy variable for foreign ownership (equal to one if the firm is foreign owned by more than 50 percent and zero otherwise). Time-varying controls include firm-specific productivity, productivity growth, average wage, and capital intensity (all with a two-year lag). For details on the propensity score reweighting estimator see the text. Robust standard errors (in parentheses) are clustered at the firm level. *,**,*** denote significance at the $10 \%, 5 \%, 1 \%$ levels, respectively.

\section{A.3.2 Worker training}

In Table 3 we identify the effect of foreign ownership on worker training without differentiating between different types of training. Here we run the same regressions as in Table 3 , but rather than lumping all types of training together, we distinguish between training in engineering, IT, language, marketing, and other (a residual category for all training expenditures not falling into any of the other four categories). In the interest of space, we report the results of three different specifications. Models A, B, and C in Table A.5 correspond, respectively, to columns (2), (4), and (5) of Table 3. Model A is based on the largest number of observations, and includes only firm fixed effects and 
industry-year fixed effects. Model B features the lowest number of observations as we add the lead and contemporaneous foreign ownership dummy along with a set of time-varying firm-level controls (lagged by two years). Model $\mathrm{C}$ uses the propensity score weighting estimator described in the main text.

\section{A.4 Further results on the market size effect}

\section{A.4.1 Technology transfer}

In Tables 4 and 5 we identify the market size effect on the hiring of recent university graduates and on worker training, respectively. Columns (5) and (6) in each table use a specific variableexport via foreign parent - to look into the role of the foreign parent in providing access to the export market and thus prompting the acquired firm to engage in skill upgrading. Another channel through which foreign ownership could lead to skill upgrading is technology transfer. If the foreign parent transfers its superior technology to the acquired firm, then this could also explain the effect of foreign ownership on skill upgrading identified in Section 4.1. To investigate this possibility, we have augmented the specifications in columns (5) and (6) of Tables 4 and 5 by a 0/1 indicator variable for assimilation of foreign technology available in the ESEE data every four years. We have also interacted this variable with the foreign ownership dummy, as assimilation of foreign technology is an activity that is not limited to firms in foreign ownership. The results in Table A.6 indicate no effect on skill upgrading associated with technology transfer from the foreign owner to the acquired firm.

\section{A.4.2 Worker training}

In Table 5 we identify the market size effect on worker training without differentiating between different types of training. Here we use the information whether firms export through the foreign parent to run the same regressions as in Table 5, but we now distinguish between different types of training. Models A and B in Table A.7 correspond, respectively, to columns (5) and (6) of Table 5. 
Table A.5: The effect of foreign ownership by type of training

\begin{tabular}{lccccc}
\hline \hline MODEL A & Engineering & IT & Morker training & & \\
Lag foreign & $0.477^{* *}$ & $0.444^{* *}$ & $0.373^{*}$ & $0.630^{* *}$ & $0.634^{* * *}$ \\
& $(0.221)$ & $(0.208)$ & $(0.192)$ & $(0.289)$ & $(0.212)$ \\
\hline Firm fixed effects & Yes & Yes & Yes & Yes & Yes \\
Industry-year fixed effects & Yes & Yes & Yes & Yes & Yes \\
Time-varying controls & & & & \\
Propensity Score & & & & & \\
\hline Observations & 17487 & 17486 & 17488 & 17486 & 17494 \\
R-squared & 0.365 & 0.329 & 0.226 & 0.338 & 0.452 \\
& & & & & \\
& & & Worker training & & \\
MODEL B & Engineering & IT & Marketing & Language & Other \\
\hline Lag foreign & 0.279 & 0.199 & 0.269 & 0.191 & 0.235 \\
& $(0.206)$ & $(0.195)$ & $(0.182)$ & $(0.269)$ & $(0.174)$ \\
Foreign & 0.0781 & 0.159 & 0.126 & 0.300 & 0.224 \\
& $(0.148)$ & $(0.147)$ & $(0.129)$ & $(0.193)$ & $(0.143)$ \\
Forward foreign & -0.159 & -0.266 & -0.197 & -0.119 & -0.126 \\
& $(0.225)$ & $(0.216)$ & $(0.233)$ & $(0.240)$ & $(0.195)$ \\
\hline Firm fixed effects & Yes & Yes & Yes & Yes & Yes \\
Industry-year fixed effects & Yes & Yes & Yes & Yes & Yes \\
Time-varying controls & Yes & Yes & Yes & Yes & Yes \\
Propensity Score & & & & & 11512 \\
Observations & 11508 & 11508 & 11508 & 0.344 & 0.455 \\
R-squared & 0.377 & 0.343 & 0.236 & &
\end{tabular}

Worker training

\begin{tabular}{|c|c|c|c|c|c|}
\hline MODEL C & Engineering & IT & Marketing & Language & Other \\
\hline \multirow[t]{2}{*}{ Lag foreign } & $0.621^{*}$ & $0.540^{* * *}$ & $0.682^{* * *}$ & $0.980^{* *}$ & $0.741^{* * *}$ \\
\hline & $(0.323)$ & $(0.200)$ & $(0.249)$ & $(0.439)$ & $(0.243)$ \\
\hline Firm fixed effects & Yes & Yes & Yes & Yes & Yes \\
\hline Industry-year fixed effects & Yes & Yes & Yes & Yes & Yes \\
\hline \multicolumn{6}{|l|}{ Time-varying controls } \\
\hline Propensity Score & Yes & Yes & Yes & Yes & Yes \\
\hline Observations & 13358 & 13358 & 13357 & 13358 & 13360 \\
\hline R-squared & 0.524 & 0.478 & 0.340 & 0.496 & 0.593 \\
\hline
\end{tabular}

Notes: The dependent variable in all columns is our measure of the stock of knowledge defined as $\tau_{i t}=\sum_{j=t_{0}}^{t} \tau_{i j}$, where $\tau_{i j}$ is a $0 / 1$ indicator variable for positive expenditures on worker training (in the specific training category indicated). Foreign is a dummy variable for foreign ownership (equal to one if the firm is foreign owned by more than 50 percent and zero otherwise). Time-varying controls include firm-specific productivity, productivity growth, average wage, and capital intensity (all with a two-year lag). For details on the propensity score reweighting estimator see the text. Robust standard errors (in parentheses) are clustered at the firm level. $* * *, * * *$ denote significance at the $10 \%, 5 \%, 1 \%$ levels, respectively. 
Table A.6: The effect of technology transfer on hiring and training

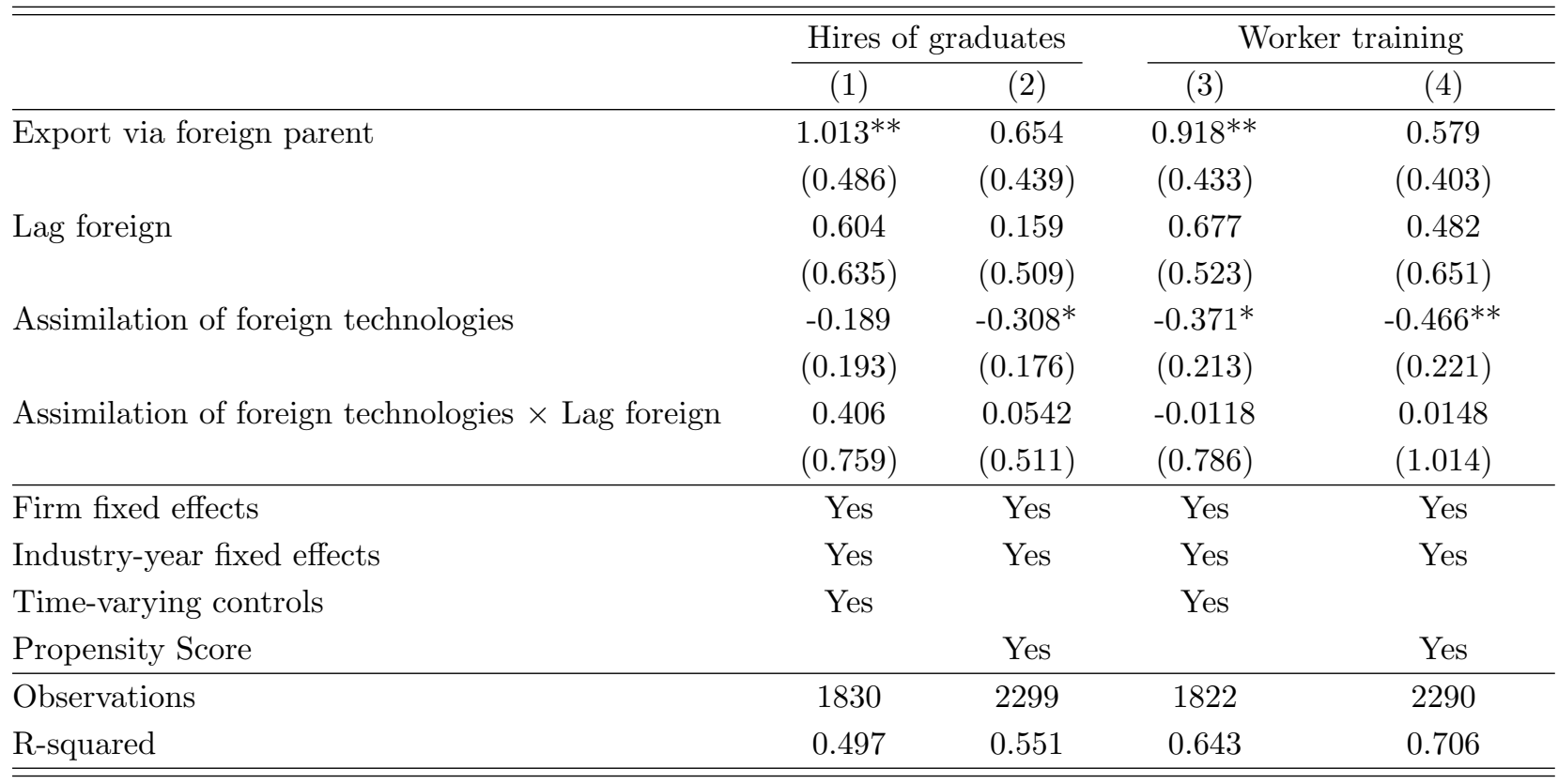

Notes: The dependent variable in columns (1) and (2) is our measure of the stock of high-skilled workers defined as $h_{i t}=\sum_{j=t_{0}}^{t} h_{i j}$, where $h_{i j}$ is a $0 / 1$ indicator variable for hires of recent university graduates. In columns (3) and (4) the dependent variable is our measure of the stock of knowledge defined as $\tau_{i t}=\sum_{j=t_{0}}^{t} \tau_{i j}$, where $\tau_{i j}$ is a $0 / 1$ indicator variable for positive expenditures on worker training (regardless of the training category). Foreign is a dummy variable for foreign ownership (equal to one if the firm is foreign owned by more than 50 percent and zero otherwise). Export via foreign parent and assimilation of foreign technologies are dummy variables indicating whether the firm carried out the respective activity in a given year. Time-varying controls include firm-specific productivity, productivity growth, average wage, and capital intensity (all with a two-year lag). For details on the propensity score reweighting estimator see the text. Robust standard errors (in parentheses) are clustered at the firm level. *,**,*** denote significance at the $10 \%, 5 \%, 1 \%$ levels, respectively. 
Table A.7: The market size effect by type of training

\begin{tabular}{|c|c|c|c|c|c|}
\hline \multirow[b]{2}{*}{ MODEL A } & \multicolumn{5}{|c|}{ Worker training } \\
\hline & Engineering & IT & Marketing & Language & Other \\
\hline \multirow[t]{2}{*}{ Export via foreign parent $1.086^{*}$} & $0.835^{*}$ & 0.531 & $0.967^{*}$ & 0.371 & \\
\hline & $(0.584)$ & $(0.488)$ & $(0.433)$ & $(0.573)$ & $(0.462)$ \\
\hline \multirow[t]{2}{*}{ Lag foreign } & -0.135 & 0.156 & 0.399 & 0.0717 & -0.203 \\
\hline & $(0.726)$ & $(0.541)$ & $(0.498)$ & $(0.804)$ & $(0.562)$ \\
\hline Firm fixed effects & Yes & Yes & Yes & Yes & Yes \\
\hline Industry-year fixed effects & Yes & Yes & Yes & Yes & Yes \\
\hline Time-varying controls & Yes & Yes & Yes & Yes & Yes \\
\hline \multicolumn{6}{|l|}{ Propensity Score } \\
\hline Observations & 1823 & 1823 & 1824 & 1822 & 1826 \\
\hline \multirow[t]{2}{*}{ R-squared } & 0.489 & 0.436 & 0.323 & 0.451 & 0.550 \\
\hline & \multicolumn{5}{|c|}{ Worker training } \\
\hline MODEL B & Engineering & $\mathrm{IT}$ & Marketing & Language & Other \\
\hline \multirow[t]{2}{*}{ Export via foreign parent } & $1.114^{* * *}$ & 0.550 & $0.547^{* *}$ & $0.891^{* *}$ & 0.138 \\
\hline & $(0.359)$ & $(0.382)$ & $(0.246)$ & $(0.442)$ & $(0.347)$ \\
\hline \multirow[t]{2}{*}{ Lag foreign } & 0.313 & 0.283 & $0.833^{* *}$ & 0.210 & -0.186 \\
\hline & $(0.562)$ & $(0.482)$ & $(0.375)$ & $(0.698)$ & $(0.434)$ \\
\hline Firm fixed effects & Yes & Yes & Yes & Yes & Yes \\
\hline Industry-year fixed effects & Yes & Yes & Yes & Yes & Yes \\
\hline \multicolumn{6}{|l|}{ Time-varying controls } \\
\hline Propensity Score & Yes & Yes & Yes & Yes & Yes \\
\hline Observations & 2299 & 2299 & 2299 & 2298 & 2303 \\
\hline R-squared & 0.561 & 0.500 & 0.364 & 0.520 & 0.601 \\
\hline
\end{tabular}

Notes: The dependent variable in all columns is our measure of the stock of knowledge defined as $\tau_{i t}=\sum_{j=t_{0}}^{t} \tau_{i j}$, where $\tau_{i j}$ is a $0 / 1$ indicator variable for positive expenditures on worker training (in the specific training category indicated). Foreign is a dummy variable for foreign ownership (equal to one if the firm is foreign owned by more than 50 percent and zero otherwise). Export via foreign parent is a dummy variable indicating whether the firm uses the foreign parent as a distribution channel to access foreign markets. Time-varying controls include firm-specific productivity, productivity growth, average wage, and capital intensity (all with a two-year lag). For details on the propensity score reweighting estimator see the text. Robust standard errors (in parentheses) are clustered at the firm level. *,**,*** denote significance at the $10 \%, 5 \%, 1 \%$ levels, respectively. 


\section{Economics Working Papers}

2016-02: John Kennes and Daniel le Maire: Competing Auctions of Skills

2016-03: $\quad$ Mette Trier Damgaard and Christina Gravert: The hidden costs of nudging: Experimental evidence from reminders in fundraising

2016-04: Sylvanus Kwaku Afesorgbor and Renuka Mahadevan: The Impact of Economic Sanctions on Income Inequality of Target States

2016-05: Martin Paldam and Erich Gundlach: Jumps into democracy: The transition in the Polity Index

2016-06: Erich Gundlach and Martin Paldam: Socioeconomic transitions as common dynamic processes

2016-07: Rune V. Lesner: Testing for Statistical Discrimination based on Gender

2016-08: $\quad$ Rune V. Lesner: The Long-Term Effect of Childhood Poverty

2016-09: $\quad$ Sylvanus Kwaku Afesorgbor: Economic Diplomacy in Africa: The Impact of Regional Integration versus Bilateral Diplomacy on Bilateral Trade

2016-10: John Kennes and Daniel le Maire: On the equivalence of buyer and seller proposals within canonical matching and pricing environments

2016-11: Ritwik Banerjee, Nabanita Datta Gupta and Marie Claire Villeval: The Spillover Effects of Affirmative Action on Competitiveness and Unethical Behavior

2017-01: Rasmus Landersø, Helena Skyt Nielsen and Marianne Simonsen: How Going to School Affects the Family

2017-02: Leslie S. Stratton, Nabanita Datta Gupta, David Reimer and Anders Holm: Modeling Enrollment in and Completion of Vocational Education: the role of cognitive and non-cognitive skills by program type

2017-03: Nabanita Datta Gupta, Anton Nielsson and Abdu Kedir Seid: Shortand Long-Term Effects of Adolescent Alcohol Access: Evidence from Denmark

2017-04: Michael Koch and Marcel Smolka: Foreign Ownership and Skill-biased Technological Change 